SANDIA REPORT SAND85-032 - Unlimited Release - UC-70

Printed September 1985

(9) $2+338-2$

\title{
Mineralogy in the Waste Isolation Pilot Plant (WIPP) Facility Stratigraphic Horizon
}

Carol L. Stein

Prepared by

Sandia National Laboratories

Albuquerque, New Mexico 87185 and Livermore, California 94550

for the United States Department of Energy

under Contract DE-AC04-76DP00789 


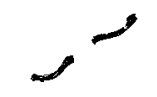

Issued by Sandia National Laboratories, operated for the United States Department of Energy by Sandia Corporation.

NOTICE: This report was prepared as an account of work sponsored by an agency of the United States Government. Neither the United States Government nor any agency thereof, nor any of their employees, nor any of their contractors, subcontractors, or their employees, makes any warranty, ex press or implied, or assumes any legal liability or responsibility for the accuracy, completeness, or usefulness of any information, apparatus, product, or process disclosed, or represents that its use would not infringe privately owned rights. Reference herein to any specific commercial product, process, or service by trade name, trademark, manufacturer, or otherwise, does not necessarily constitute or imply its endorsement, recommendation or favoring by the United States Government, any agency thereof or any of their contractors or subcontractors. The views and opinions expressed herein do not necessarily state or reflect those of the United States Government, any agency thereof or any of their contractors or subcontractors.

Printed in the United States of America Available from

National Technical Information Service

U.S. Department of Commerce

5285 Port Royal Road

Springfield, VA 22161

NTIS price codes

Printed copy: A03

Microfiche copy: A0I

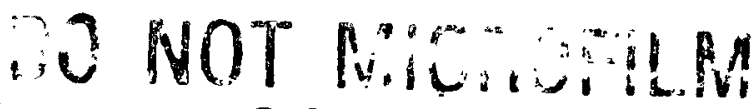 COVER}




\section{DISCLAIMER}

This report was prepared as an account of work sponsored by an agency of the United States Government. Neither the United States Government nor any agency Thereof, nor any of their employees, makes any warranty, express or implied, or assumes any legal liability or responsibility for the accuracy, completeness, or usefulness of any information, apparatus, product, or process disclosed, or represents that its use would not infringe privately owned rights. Reference herein to any specific commercial product, process, or service by trade name, trademark, manufacturer, or otherwise does not necessarily constitute or imply its endorsement, recommendation, or favoring by the United States Government or any agency thereof. The views and opinions of authors expressed herein do not necessarily state or reflect those of the United States Government or any agency thereof. 


\section{DISCLAIMER}

Portions of this document may be illegible in electronic image products. Images are produced from the best available original document. 
SAND85-0321

Distribution

Unlimited Release

Category UC -70

Printed September 1985

\title{
Mineralogy in the Waste Isolation Pilot Plant (WIPP) Facility Stratigraphic Horizon
}

\author{
Carol L. Stein \\ Earth Sciences Division \\ Sandia National Laboratories \\ Albuquerque, NM 87185
}

\begin{abstract}
Forty-six samples were selected for this study from two cores, one extending $50 \mathrm{ft}$ up through the roof of the WIPP facility and the other penetrating $50 \mathrm{ft}$ below the facility floor. These samples, selected from approximately every other foot of core length, represent the major lithologies present in the immediate vicinity of the WIPP facility horizon: "clean" halite, polyhalitic halite, argillaceous halite, and mixed polyhalitic-argillaceous halite. Samples were analyzed for non$\mathrm{NaCl}$ mineralogy by determining weight percents of water- and EDTA-insoluble residues, which were then identified by $\mathrm{x}$-ray diffraction. In general, WIPP halite contains at most $5 \mathrm{wt} \%$ non$\mathrm{NaCl}$ residue. The major mineral constituents are quartz, magnesite, anhydrite, gypsum, polyhalite, and clays. Results of this study confirm that, in previous descriptions of WIPP core, trace mineral quantities have been visually overestimated by approximately an order of magnitude.
\end{abstract}

\section{DISCLAIMER}

This report was prepared as an account of work sponsored by an agency of the United States Government. Neither the United States Government nor any agency thereof, nor any of their bility for the accuracy, completeness, or usefulness or assumes any legal liability or responsiprocess disclosed, or represents that its use would of any information, apparatus, product, or ence herein to any specific commercial product, process, or privately owned rights. Refermanufacturer, or otherwise does not necessarily constitute service by trade name, trademark, mendation, or favoring by the United States Government or imply its endorsement, recomand opinions of authors expressed herein Government or any agency thereof. The views United States Government or any agency thereof.

SAND- $-85-0321$

DE86 000571 


\section{Acknowledgments}

Gautam Sarkar, a graduate student in the Geology Department at the University of New Mexico, provided the weight-percent data and the $x$-ray diffraction analyses of the non- $\mathrm{NaCl}$ mineral residues. His attention to detail throughout both phases of this timeconsuming project is gratefully acknowledged. In addition, I thank Klaus Keil of the Institute of Meteoritics, the UNM Geology Department, for his assistance and for many helpful discussions. The manuscript was much improved by the reviews provided by David J. Borns of Division 6331 and by Klaus Keil. 


\section{Contents}

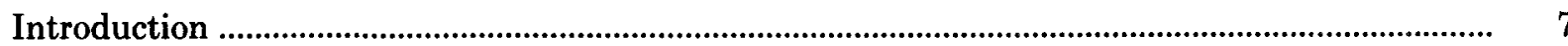

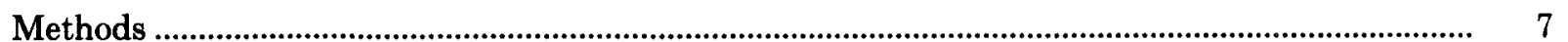

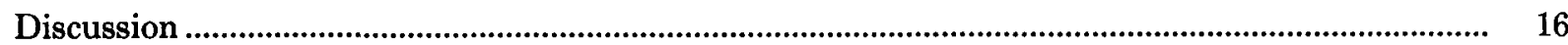

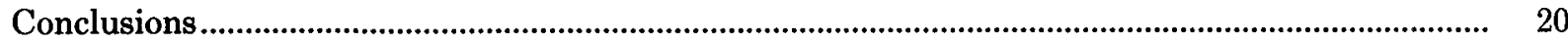

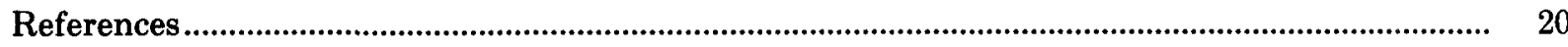

APPENDIX A-Lithologic Logs ..........................................................................................

APPENDIX B-Description of Core Samples Used In This Study ............................................

\section{Figures}

1 Map of underground workings showing location of Test Room 4 and location of core holes

2 Scanning electron micrographs of authigenic quartz crystals found in waterinsoluble residues from argillaceous halite $((a)-(c))$ and thin section photomicrograph of authigenic quartz crystals in recrystallized halite (d)

3 Comparison of three different methods of detection of non- $\mathrm{NaCl}$ mineralogy by using surplus core from the WIPP facility horizon: (a) gamma-beam densitometry, (b) x-radiography, and (c) conventional dissolution technique

Core RM-1, showing lithologies and amounts of water- and EDTA-insoluble residues .........

5 Core RM-3, showing lithologies and amounts of water- and EDTA-insoluble residues ........

\section{Tables}

1 Weight Percents of Water-Insoluble Residues

2 X-Ray Diffraction Results from Water-Insoluble Residues ................................................... 10

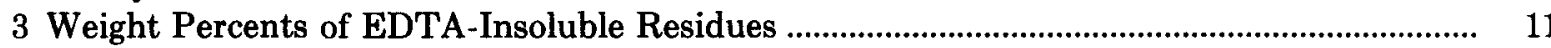

4 X-Ray Diffraction Results from EDTA-Insoluble Residues ................................................ 12

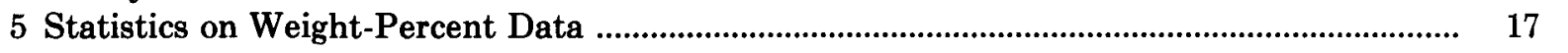




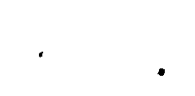




\section{Mineralogy in the Waste Isolation Pilot Plant (WIPP) Facility Stratigraphic Horizon}

\section{Introduction}

As part of the Waste Isolation Pilot Plant (WIPP) continued geotechnical studies, Sandia National Laboratories (SNL) has been charged with the task of producing a detailed characterization of the geologic interval in the immediate vicinity of the WIPP facility. Preliminary work toward this end was begun in 1983 with the Site and Preliminary Design Validation (SPDV) report. The SPDV work includes a comprehensive mineralogical analysis of 43 rock samples taken at or near the facility horizon. These samples consisted primarily of grab samples taken from the excavation face as mining proceeded, and of selected samples from cores taken from some of the excavated rooms. These samples were processed for their mineralogical components by a method described in detail in the final SPDV report (Stein, 1983) and summarized elsewhere in this report. The end result was a compilation of data that quantitatively describe the non- $\mathrm{NaCl}$ portion of the host halite in the general stratigraphic vicinity of the WIPP facility horizon.

An important conclusion from this set of data is that, up until the time of the SPDV report, visual estimates of the non- $\mathrm{NaCl}$ components were incorrect by as much as an order of magnitude or more. The appearance of the Salado halite can be deceptive, especially when it contains small quantities of very fine-grained, disseminated polyhalite or clay minerals. In summary, from the SPDV work it was learned that WIPP halite contains an average maximum of $5 \mathrm{wt} \%$ non- $\mathrm{NaCl}$ mineralogy, except in the cases of units such as anhydrites and clay seams.

This information was, in turn, used to revise some of the ongoing work directed toward predicting longterm creep behavior of the salt around the excavated cavity. However, one shortcoming of the SPDV work concerned the distribution of the sample locations of the analyzed material. It was felt that a more comprehensive body of data could be obtained by using samples from precisely known locations and could be collected on a more tightly spaced grid. Moreover, the plan for the sampling program that was ultimately adopted also provided for samples to be taken simultaneously for rock mechanics testing by $\mathrm{W}$. Wawersik
(SNL, Division 1542). Lastly, executing this program provided a set of reference samples for the purpose of making more quantitative visual comparisons of rock samples and a suite of archived core that will remain on file at the WIPP site for future reference.

\section{Methods}

The samples selected for this study were taken primarily from two cores, each $\sim 50 \mathrm{ft}$ long and $4 \frac{1}{2}$ in. diameter, that were cut in Test Room 4 of the WIPP facility (see map, Figure 1). These cores were cut with a Longyear 38 drill rig, using no liquid lubricant. The cores used in this study are designated RM-1 and RM-3; these were cut vertically upward into the roof, and directly opposite were cut vertically downward, respectively. The lithologic logs for these cores are shown in Appendix A.

Samples were chosen from approximately every other foot along the length of the cores. Brief descriptions of the portions selected, along with sample numbers and footages, are listed in Appendix B. Samples were selected from each of the dominant lithologies observed in the core. These are: (1) "clean" halite, (2) polyhalitic halite, (3) argillaceous halite, (4) mixed argillaceous-polyhalitic halite, and (5) anhydrites and clay seams. These samples, each $\sim 6$ in. long, were subsequently slabbed; one half was sent to Sandia for processing and analysis; the other remained in Carlsbad for the reference collection.

The technique used to process these samples has been described in detail (Stein, 1983). To summarize briefly, the samples, weighing from $\sim 200 \mathrm{~g}$ to $\sim 1 \mathrm{~kg}$, were crushed to pieces the size of $\leq 1 \mathrm{~cm}^{3}$. Weighed amounts of samples were then placed in large beakers of distilled water and stirred continuously until all salt was dissolved. The beakers were then decanted and the remaining residues were collected by filtration onto preweighed Whatman \#3 filter papers, allowed to air-dry, and then weighed again. The dry weights of the water-insoluble residues are reported in Table 1. Small fractions of these residues were reserved for $x$-ray diffraction analysis; results are shown in Table 2. The 
remaining portions were further processed by boiling for $4 \mathrm{hr}$ (or longer, as necessary) in 0.25-M EDTA solution. This technique, developed by Bodine and Fernalld (1973), removes all divalent carbonates and sulfates from the water-insoluble residues. Following boiling, the samples were again collected onto preweighed Whatman \#3 filter papers, dried, and weighed again to obtain the EDTA-insoluble residue weights (shown as weight percents) in Table 3 . As before, where sample material was abundant enough, $\mathrm{x}$-ray diffraction analyses were performed. These results are shown in Table 4.

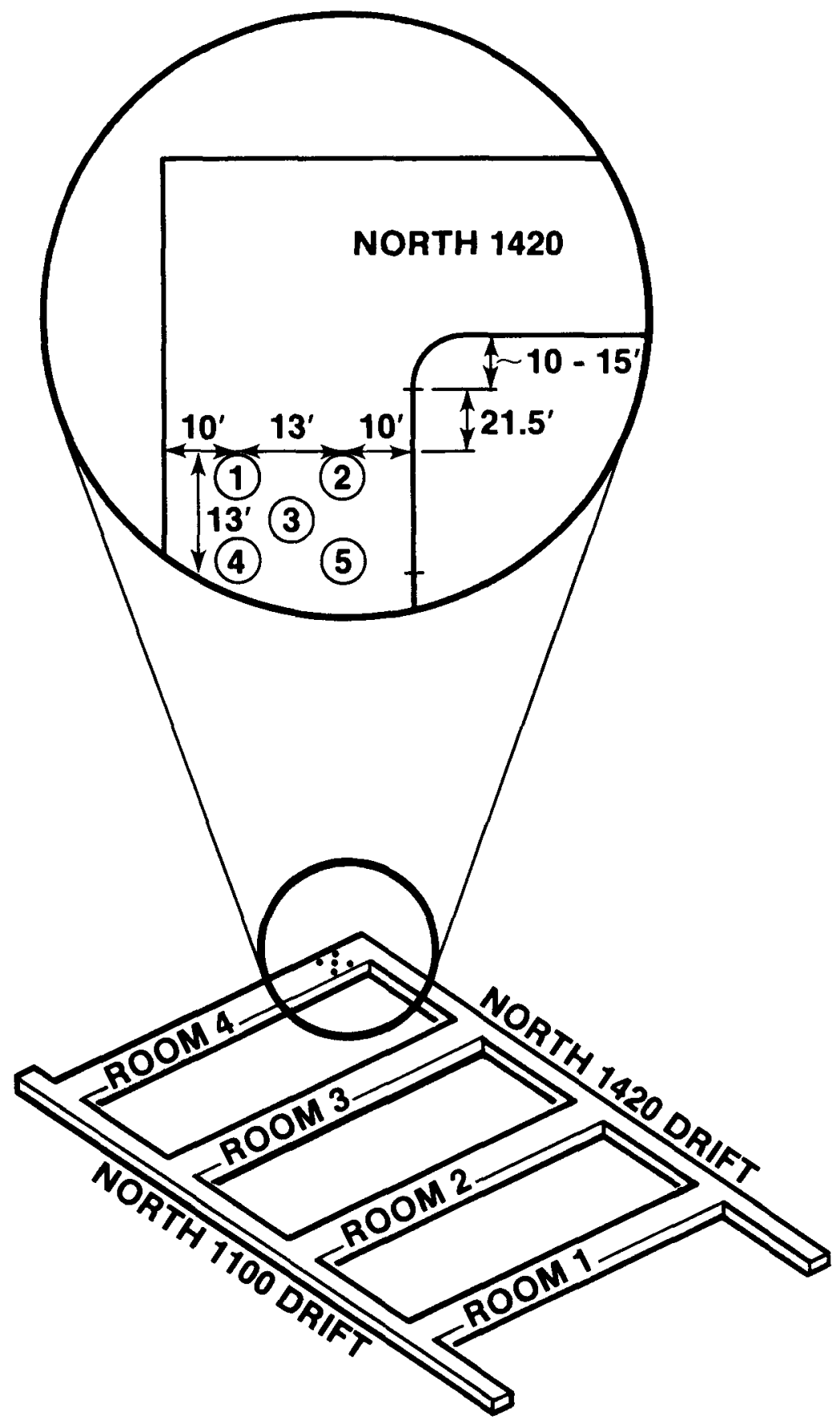

Figure 1. Map of underground workings (from Bechtel, 1985) showing location of Test Room 4 and location of core holes. (Note: Cores RM-3 and RM-4 are down; Cores RM-1 and RM-7 (not shown) are up.) 
Table 1. Weight Percents of Water-Insoluble Residues

\begin{tabular}{|c|c|c|c|c|c|}
\hline \multirow[t]{2}{*}{$\begin{array}{c}\text { Sample } \\
\text { No. }\end{array}$} & \multicolumn{2}{|c|}{$\begin{array}{c}\text { Sample } \\
\text { Depth } \\
\text { (ft) }\end{array}$} & \multirow[t]{2}{*}{$\begin{array}{c}\text { Sample } \\
\text { Weight } \\
\text { (g) }\end{array}$} & \multirow[t]{2}{*}{$\begin{array}{l}\text { Weight of Water- } \\
\text { Insoluble Residue } \\
\text { (g) }\end{array}$} & \multirow[t]{2}{*}{$\begin{array}{c}\text { Weight \% } \\
\text { (whole rock) }\end{array}$} \\
\hline & From & To & & & \\
\hline FH-201 & 2 & 2.5 & 757 & 2.76 & 0.36 \\
\hline FH-202 & 4 & 4.7 & 482 & 165.58 & 34.35 \\
\hline FH-203 & 8.3 & 9 & 649 & 13.09 & 2.02 \\
\hline FH-204 & 10.8 & 11.3 & 734 & 6.83 & 0.93 \\
\hline FH-205 & 13 & 13.55 & 715 & 0.38 & 0.05 \\
\hline FH-206 & 15.55 & 15.85 & 696 & 27.05 & 3.89 \\
\hline FH-207 & 16.9 & 17.45 & 700 & 1.41 & 0.2 \\
\hline FH-208 & 18.4 & 19.1 & 670.2 & 2.69 & 0.4 \\
\hline FH-209 & 19.65 & 20.05 & 641.3 & 1.1 & 0.17 \\
\hline FH-210 & 21.5 & 22 & 742.55 & 13.86 & 1.87 \\
\hline FH-211 & 23 & 23.5 & 700 & 3.6 & 0.51 \\
\hline FH-212 & 25.1 & 25.7 & 700 & 5.7 & 0.81 \\
\hline FH-213 & 26 & 26.5 & 700 & 4.57 & 0.65 \\
\hline FH-214 & 28.25 & 28.85 & 751 & 1.54 & 0.205 \\
\hline FH-215 & 30.5 & 31.05 & 700 & 0.47 & 0.07 \\
\hline FH-216 & 31 & 38 & 674 & 9.93 & 1.47 \\
\hline FH-217 & 39.25 & 39.85 & 535 & 13.42 & 2.51 \\
\hline FH-218 & 41 & 41.5 & 617.5 & 10.95 & 1.77 \\
\hline FH-219 & 42.5 & 43 & 676.5 & 21.13 & 3.12 \\
\hline FH-220 & 44 & 44.5 & 700 & 8.72 & 1.245 \\
\hline FH-221 & 45.3 & 45.85 & 743.85 & 4.04 & 0.54 \\
\hline FH-222 & 47 & 47.5 & 747.5 & 5.94 & 0.79 \\
\hline FH-223 & 49.05 & 49.55 & 739.5 & 2.2 & 0.3 \\
\hline FH-224 & 4 & $4.5^{* *}$ & 385.6 & 235.74 & 61.14 \\
\hline \multicolumn{6}{|c|}{$\begin{array}{l}\text { *core loss zone } \\
{ }^{* *} \text { From RM-4 }\end{array}$} \\
\hline FH-228 & 0.4 & 0.9 & 1,000 & 1.425 & 0.14 \\
\hline FH-229 & 2.3 & 2.8 & 1,000 & 0.77 & 0.08 \\
\hline FH-230 & 4.75 & 6.75 & 1,000 & 2.38 & 0.24 \\
\hline FH-231 & 7.1 & 7.3 & 600 & 169.89 & 28.32 \\
\hline FH-232 & 7.75 & 8.15 & 900 & 3.27 & 0.36 \\
\hline FH-233 & 8.15 & 9.1 & 1,000 & 0.45 & 0.05 \\
\hline FH-234 & 10.5 & 10.9 & 1,000 & 13.46 & 1.35 \\
\hline $\mathrm{FH}-235$ & 12.5 & 12.6 & 1,000 & 2.87 & 0.29 \\
\hline FH-236 & 14 & 14.45 & 200 & 174.15 & 87.08 \\
\hline FH-237 & 16.1 & 16.6 & 700 & 12.99 & 1.86 \\
\hline FH-238 & 29 & 29.5 & 550 & 34.68 & 6.31 \\
\hline FH-239 & 34.05 & 34.5 & 600 & 18.58 & 3.1 \\
\hline FH-240 & 36.9 & 37.6 & 700 & 184.11 & 26.3 \\
\hline FH-241 & 38.2 & 38.7 & 1,000 & 3.04 & 0.3 \\
\hline FH-242 & 43.05 & 43.55 & 600 & 9.7 & 1.62 \\
\hline $\mathrm{FH}-243$ & 47.2 & 47.7 & 850 & 6.41 & 0.75 \\
\hline FH-244 & 49.65 & 50 & 300 & 29.03 & 9.68 \\
\hline FH-245 & 51.3 & 52.1 & 400 & 37.19 & 9.3 \\
\hline FH-246* & 20.05 & 20.45 & 1,000 & 8 & 0.8 \\
\hline $\mathrm{FH}-247^{*}$ & 23.45 & 23.95 & 600 & 81.2 & 13.53 \\
\hline $\mathrm{FH}-248^{*}$ & 25.5 & 26 & 1,000 & 0.47 & 0.05 \\
\hline FH-249* & 45 & 45.65 & 900 & 4.96 & 0.55 \\
\hline${ }^{*}$ From $R$ & & & & & \\
\hline
\end{tabular}




\section{Table 2. X-Ray Diffraction Results from Water-Insoluble Residues}

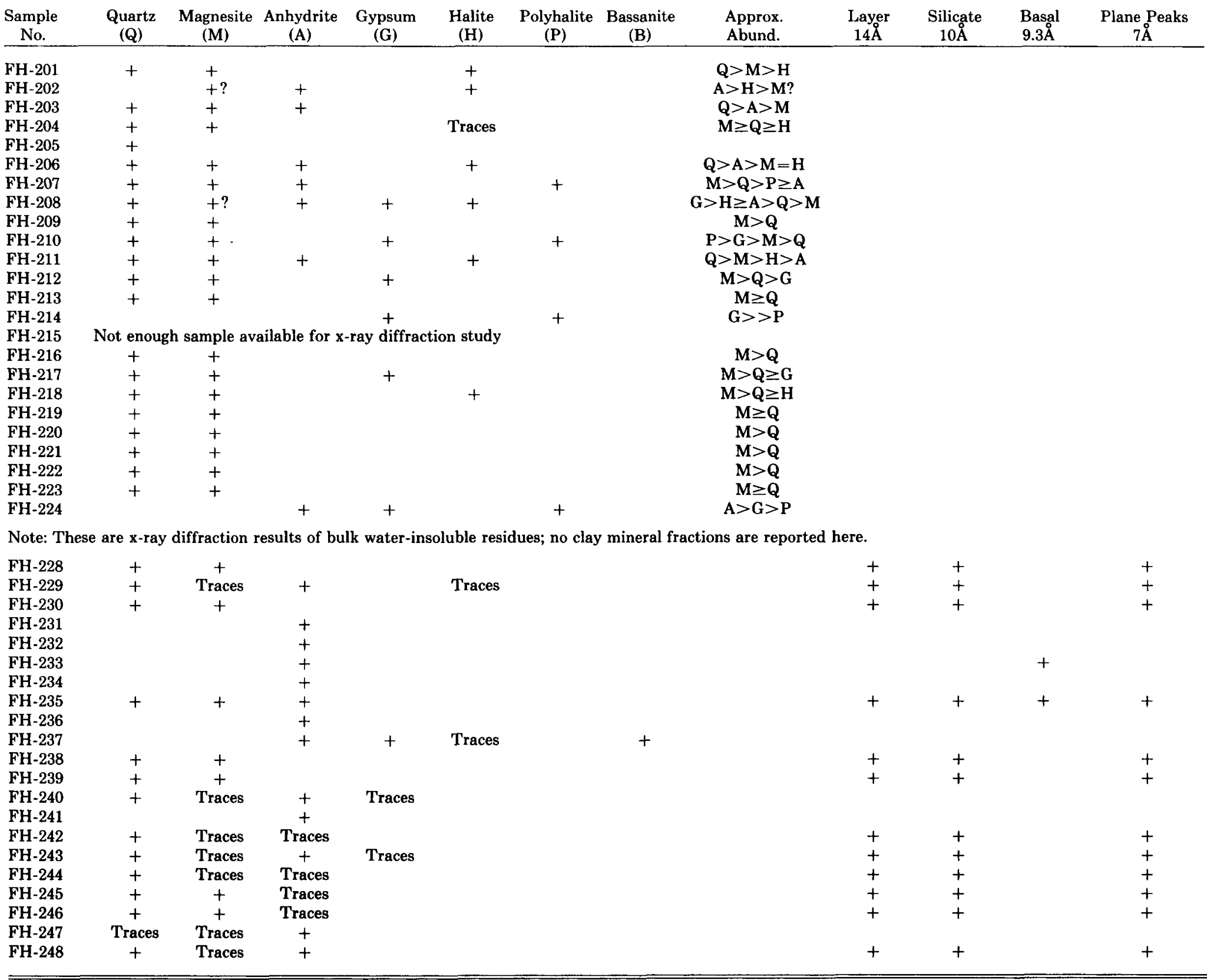




\section{Table 3. Weight Percents of EDTA-Insoluble Residues}

\begin{tabular}{|c|c|c|c|c|c|c|}
\hline \multirow[t]{2}{*}{$\begin{array}{c}\text { Sample } \\
\text { No. } \\
\end{array}$} & \multicolumn{2}{|c|}{$\begin{array}{l}\text { Sample } \\
\text { Depth } \\
\text { (ft) }\end{array}$} & \multirow[t]{2}{*}{$\begin{array}{c}\text { Sample } \\
\text { Weight } \\
\text { (g) }\end{array}$} & \multirow[t]{2}{*}{$\begin{array}{l}\text { Weight of EDTA- } \\
\text { Insoluble Residue } \\
\text { (g) }\end{array}$} & \multirow[t]{2}{*}{$\begin{array}{c}\text { Weight \% } \\
\text { (water-insoluble } \\
\text { residue) }\end{array}$} & \multirow[t]{2}{*}{$\begin{array}{c}\text { Weight \% } \\
\text { (whole rock) }\end{array}$} \\
\hline & From & To & & & & \\
\hline 201 & 2 & 2.5 & 1.025 & 0.6 & 58.54 & 0.21 \\
\hline 202 & 4 & 4.7 & 4 & 0.02 & 0.5 & 0.17 \\
\hline 203 & 8.3 & 9 & 3 & 0.97 & 32.33 & 0.65 \\
\hline 204 & 10.8 & 11.3 & 3 & 1.55 & 51.67 & 0.48 \\
\hline 205 & 13 & 13.55 & Insufficient material & & & \\
\hline 206 & 15.55 & 15.85 & 4 & 2.11 & 52.75 & 2.05 \\
\hline 207 & 16.9 & 17.45 & 0.53 & 0.27 & 50.94 & 0.1 \\
\hline 209 & 19.65 & 20.05 & 0.52 & 0.19 & 36.54 & 0.06 \\
\hline 210 & 21.5 & 22 & 4 & 0.6 & 15 & 0.28 \\
\hline 211 & 23 & 23.5 & 2.1 & 1.03 & 49.05 & 0.25 \\
\hline 212 & 25.1 & 25.7 & 4 & 2.1 & 52.5 & 0.425 \\
\hline 213 & 26 & 26.5 & 3.65 & 1.935 & 53.01 & 0.34 \\
\hline 214 & 28.25 & 28.85 & 0.9 & 0.055 & 6.11 & 0.0125 \\
\hline 215 & 30.5 & 31.05 & Insufficient material & & & \\
\hline 216 & 31 & $38^{*}$ & 4 & 2.43 & 60.75 & 0.89 \\
\hline 217 & 39.25 & 39.85 & 4 & 1.5 & 37.5 & 0.94 \\
\hline 218 & 41 & 41.5 & 4 & 1.95 & 48.75 & 0.86 \\
\hline 219 & 42.5 & 43 & 4 & 2.27 & 56.75 & 1.77 \\
\hline 220 & 44 & 44.5 & 4 & 2.61 & 65.25 & 0.81 \\
\hline 221 & 45.3 & 45.85 & 2.3 & 1.48 & 64.35 & 0.35 \\
\hline 222 & 47 & 47.5 & 4 & 2.3 & 57.5 & 0.45 \\
\hline 223 & 49.05 & 49.55 & 1.075 & 0.46 & 42.79 & 0.13 \\
\hline 224 & 4 & $4.5^{* *}$ & 4 & 0.06 & 1.5 & 0.92 \\
\hline
\end{tabular}

${ }^{*}$ Core loss zone

**From RM-4

$\begin{array}{lllllll}228 & 0.4 & 0.9 & 0.7 & 0.255 & 36.4 & 0.05 \\ 229 & 2.3 & 2.8 & 0.475 & 0.15 & 31.6 & 0.025 \\ 230 & 4.75 & 6.75 & 2.075 & 0.955 & 46 & 0.11 \\ 231 & 7.1 & 7.3 & 4.1 & 0.005 & 0.12 & 0.03 \\ 232 & 7.75 & 8.15 & 3 & 0.21 & 7 & 0.025 \\ 233 & 8.15 & 9.1 & 0.38 & 0.09 & 23.7 & 0.01 \\ 234 & 10.5 & 10.9 & 3 & 0.005 & 0.17 & 0.002 \\ 235 & 12.15 & 12.6 & 2.5 & 0.65 & 26 & 0.001 \\ 236 & 14 & 14.45 & 3 & 0.007 & 0.23 & 0.2 \\ 237 & 16.1 & 16.6 & 3 & 0.16 & 5.3 & 0.1 \\ 238 & 29 & 29.5 & 2.9 & 1.29 & 44.5 & 2.81 \\ 239 & 34.05 & 34.5 & 3 & 1.315 & 43.8 & 1.36 \\ 240 & 36.9 & 37.6 & 3 & 0.07 & 2.3 & 0.6 \\ 241 & 38.2 & 38.7 & 2.8 & 0.02 & 0.71 & 0.002 \\ 242 & 43.05 & 43.55 & 3 & 2.03 & 67.7 & 1.1 \\ 243 & 47.2 & 47.7 & 3 & 0.86 & 28.7 & 0.215 \\ 244 & 49.65 & 50 & 3 & 1.76 & 58.7 & 5.68 \\ 245 & 51.3 & 52.1 & 2.7 & 0.645 & 23.9 & 2.22 \\ 246^{*} & 20.05 & 20.45 & 3 & 1.09 & 36.3 & 0.29 \\ 247^{*} & 23.45 & 23.95 & 3 & 0.08 & 2.67 & 0.36 \\ 248^{*} & 25.5 & 26 & 0.36 & 0.09 & 25 & 0.0125 \\ 249^{*} & 45 & 45.65 & 3 & 1.37 & 45.7 & 0.25\end{array}$

${ }^{*}$ From core RM-7 
Table 4. X-Ray Diffraction Results from EDTA-Insoluble Residues

\begin{tabular}{|c|c|c|c|c|c|c|}
\hline $\begin{array}{c}\text { Sample } \\
\text { No. }\end{array}$ & Quartz & Anhydrite & Magnesite & Polyhalite & $\begin{array}{c}\text { Basal Planar } \\
14 \dot{A} \\
\end{array}$ & $\begin{array}{c}\text { Spacings } \\
10 \AA \\
\end{array}$ \\
\hline FH-201 & + & & & & & \\
\hline FH-202 & Insufficient & aterial & & & & \\
\hline FH-203 & + & & & & & + \\
\hline FH-204 & + & & & & & \\
\hline FH-205 & Insufficient & aterial & & & & \\
\hline FH-206 & + & & & & & \\
\hline FH-207 & Insufficient & aterial & & & & \\
\hline FH-208 & + & & & & & \\
\hline FH-209 & Insufficient & aterial & & & & \\
\hline FH-210 & + & Traces & & Traces & & \\
\hline FH-211 & + & & & & + & + \\
\hline FH-212 & + & Traces & & & & \\
\hline FH-213 & + & & Traces & & + & + \\
\hline FH-214 & + & & & & & \\
\hline FH-215 & Insufficien & aterial & & & & \\
\hline FH-216 & + & & & & & \\
\hline FH-217 & + & & & & & + \\
\hline FH-218 & + & & & & & \\
\hline FH-219 & + & & & & + & + \\
\hline FH-220 & + & & & & & \\
\hline FH-221 & + & & & & + & + \\
\hline FH-222 & + & & & & + & + \\
\hline FH-223 & + & & & & + & + \\
\hline FH-224 & Insufficien & laterial & & & & \\
\hline
\end{tabular}

The components of the non- $\mathrm{NaCl}$ mineral residues were identified by $x$-ray diffraction. All x-ray analyses for this study were run by using a Phillips diffractometer with $\mathrm{Cu} \mathrm{K} \alpha$ radiation at an operating voltage of $40 \mathrm{keV}$ and $25 \mathrm{~mA}$. The x-ray diffraction results obtained are at best only semiquantitative. Because of time constraints on the analyst and because of the limited amount of available sample material, it was decided to forego any attempts at more quantitative $\mathrm{x}$-ray diffraction analysis at this time. Where indicated in Table 2, relative amounts of mineral species are reported on the bases of the analyst's inspection of the diffractograms and on his knowledge of the relative diffraction efficiencies of the different minerals present.
Some of the water- and EDTA-insoluble residue samples were observed to contain significant quantities of minute, well-developed, euhedral quartz crystals. A few of these crystals were hand-picked from selected water-insoluble residue samples by means of a binocular microscope and surgical tweezers. These crystals were then mounted on carbon bases and examined with a scanning electron microscope (SEM), as seen in Figure 2 (a-c). In addition to this quartz, very small $(\ll 10 \mu \mathrm{m})$ euhedral crystals of magnesite and $\mathrm{Mg}$-silicate phases were also observed with the SEM and identified as to elemental content by EDAX. 


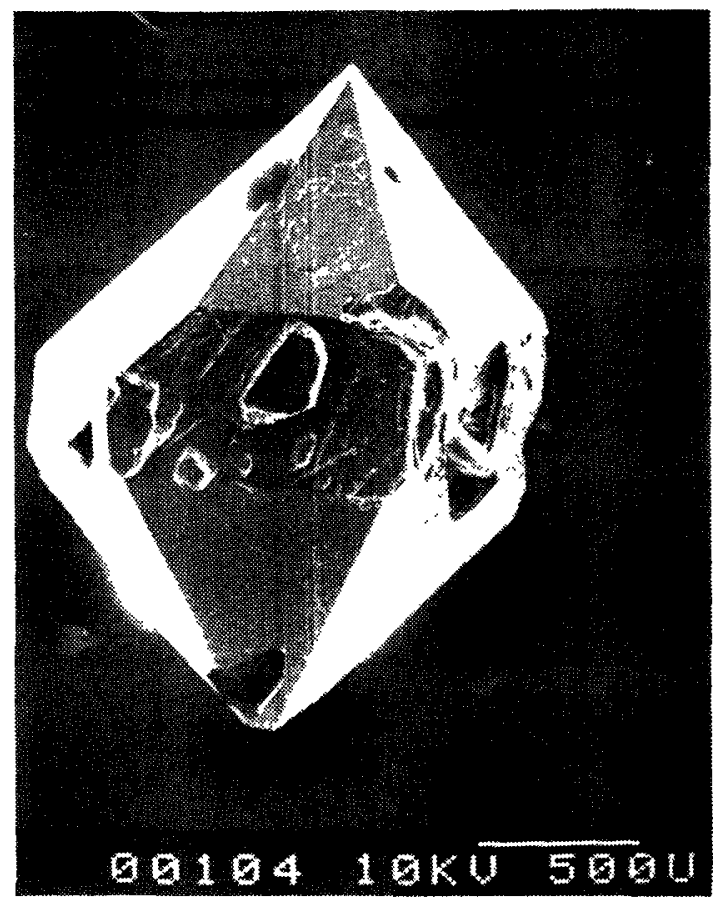

(a)

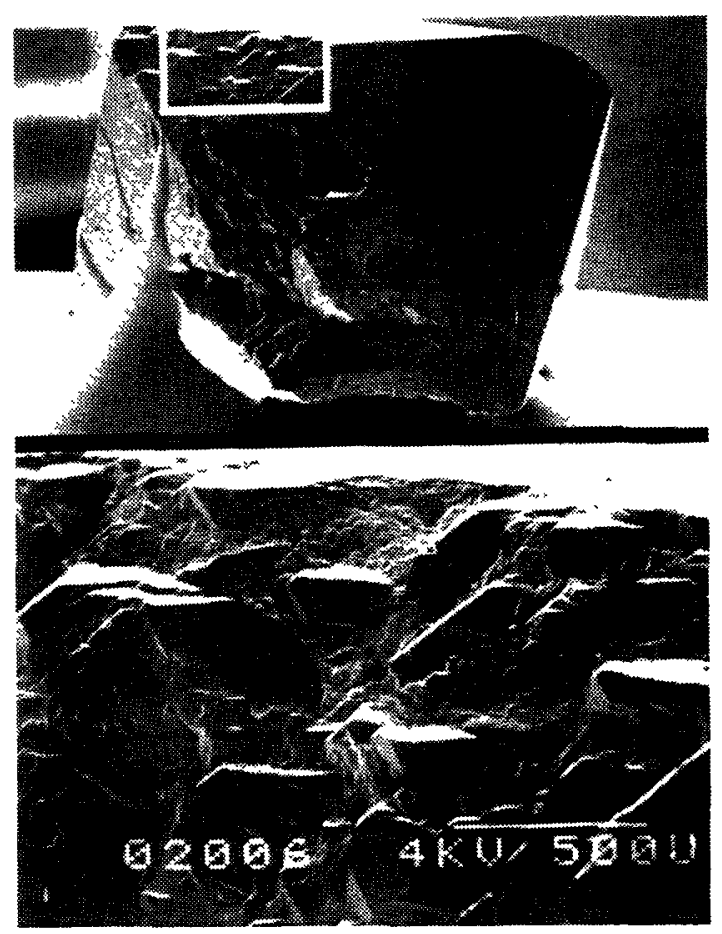

(c)

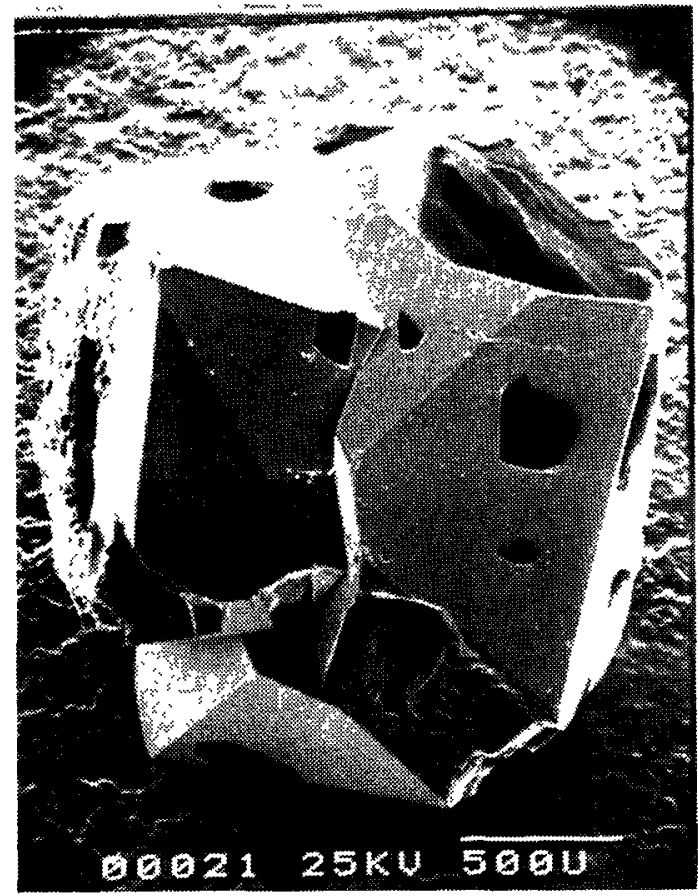

(b)

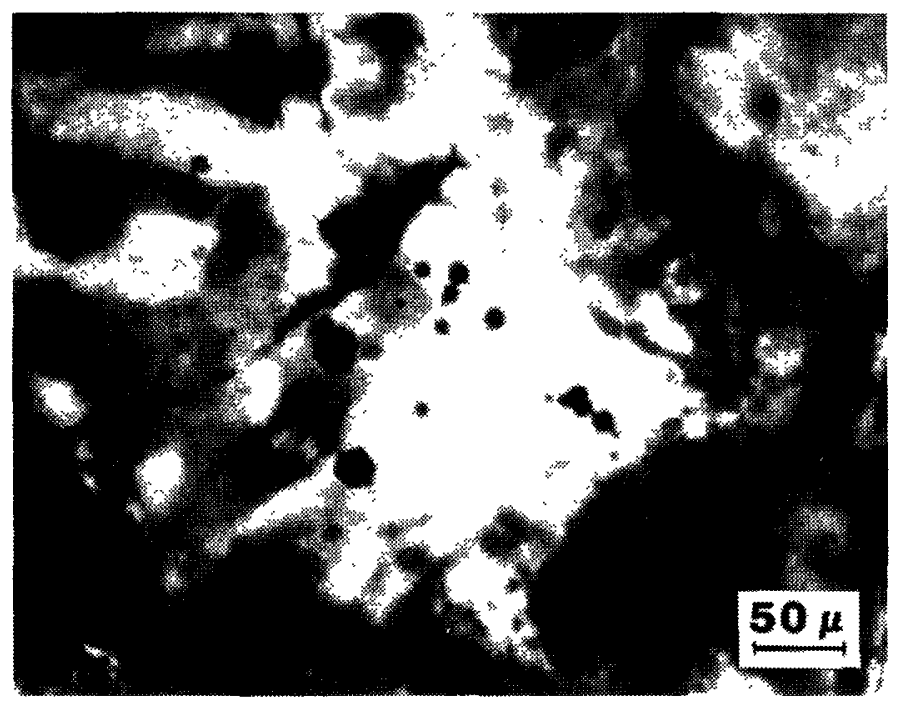

(d)

Figure 2. Scanning electron micrographs of authigenic quartz crystals found in water-insoluble residues from argillaceous halite ((a) - (c)) and thin section photomicrograph of authigenic quartz crystals in recrystallized halite (d). 
The routine analytical procedure used in this study to determine weight percents of non- $\mathrm{NaCl}$ minerals, as described above, has two limitations: (1) it is time-consuming and labor-intensive; (2) this process yields weight percents of non- $\mathrm{NaCl}$ minerals as an average for a bulk sample; no information is obtained regarding the spatial distribution of these minerals within that sample. Therefore, two possible alternative techniques, gamma-beam densitometry and $x$-radiography, were selected on the basis of the following criteria:

- Rapid data acquisition: relative to the conventional analytical method described above, which requires weeks or months to process up to several meters of core, gamma-beam densitometry and $x$-radiography can analyze the same amount of core in hours or minutes, respectively.

- Continuous data collection: the information output is obtained from a continuous scan of the core, yielding far more data than integrating bulk mineralogy over a 500 -g sample, while simultaneously showing the desired spatial distribution of non- $\mathrm{NaCl}$ components.

- Sample handling and preparation: whole core was used for x-radiography, and only surface milling in a lathe was required for the gamma beam densitometer. Because both of these techniques are nondestructive, the information thus obtained may then be supplemented by thin sections or other mineralogical analyses.

A "trial" halite core (actually, a scrap core of unspecified location within the facility horizon) was selected on the basis of the apparent presence of large and variable amounts of clays and other mineral impurities as ascertained by visual inspection. This core was first subjected to scanning by a gamma-beam attenuation system accountable to Sandia's Department 1510. For further details of this procedure, see Reda and Hadley (1983). This technique uses a $\mathrm{Cs}^{137}$ source to produce a photon beam. The attenuation coefficient, $\mu$, of this beam through the core material is compared to the measured value for a reference sample of pure salt $\left(\mu_{\mathrm{ref}}\right)$. The results of the gamma-beam densitometer scan are shown in Figure 3(a).

The same piece of core was also subjected to $x$ radiography and the film then read by microdensitometry; results are shown in Figure 3(b). A large fracture in the core, which showed up on the $\mathrm{x}$-radiograph as a dark line, is offset from the position of the same fracture on the gamma-beam densitometer plot (Figures $3(a)$ and $3(b))$ as a result of the slight rotation of the core from its position in the $\mathrm{x}$-radiographs.

Finally, the core was sliced into $\sim 1$-in. pieces and dissolved in distilled water according to the routine procedure. The total dry weight percent of mineral residue is plotted in Figure 3(b) and represents an average value over every 1 -in. length of core.

Gamma-beam densitometry appears to be the least suitable of these techniques for detecting mineral impurities in halite core. No obvious correlation exists between the data in Figure 3(a) and in Figure 3(c). The x-radiograph results, however, may be fit by a smooth curve that reasonably approximates the conventional analytical data (Figures $3(\mathrm{~b})$ and $3(\mathrm{c})$, respectively) exclusive of such features as peaks corresponding to obvious fractures. 


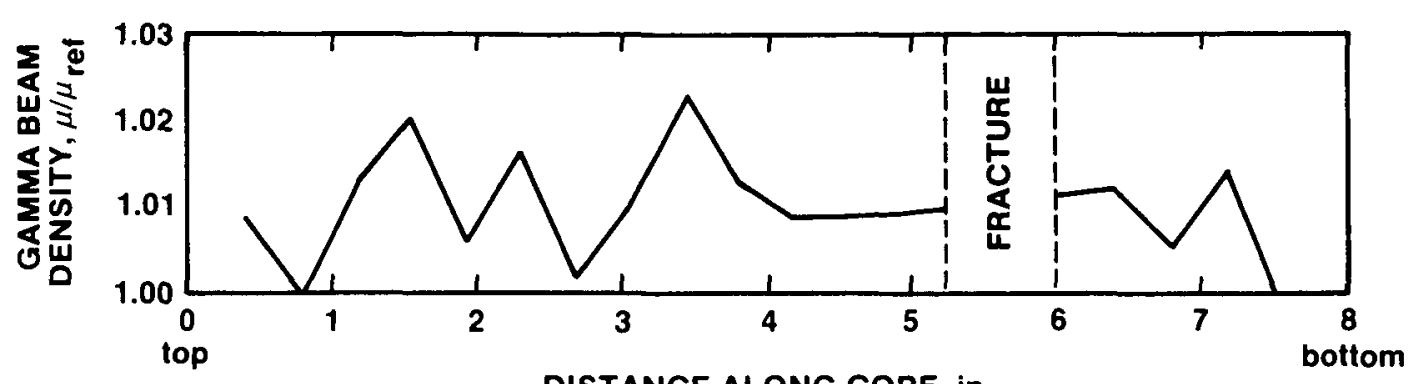

DISTANCE ALONG CORE, in.

(a)

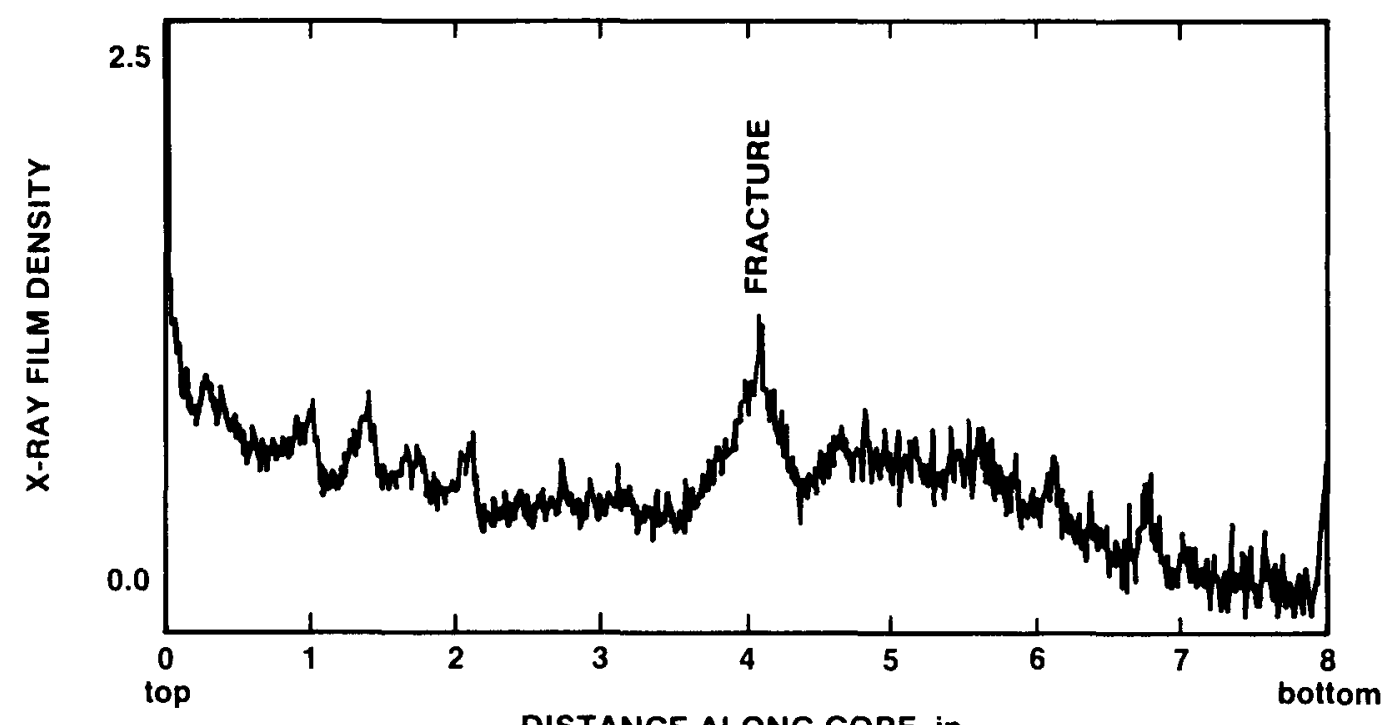

DISTANCE ALONG CORE, in.

(b)

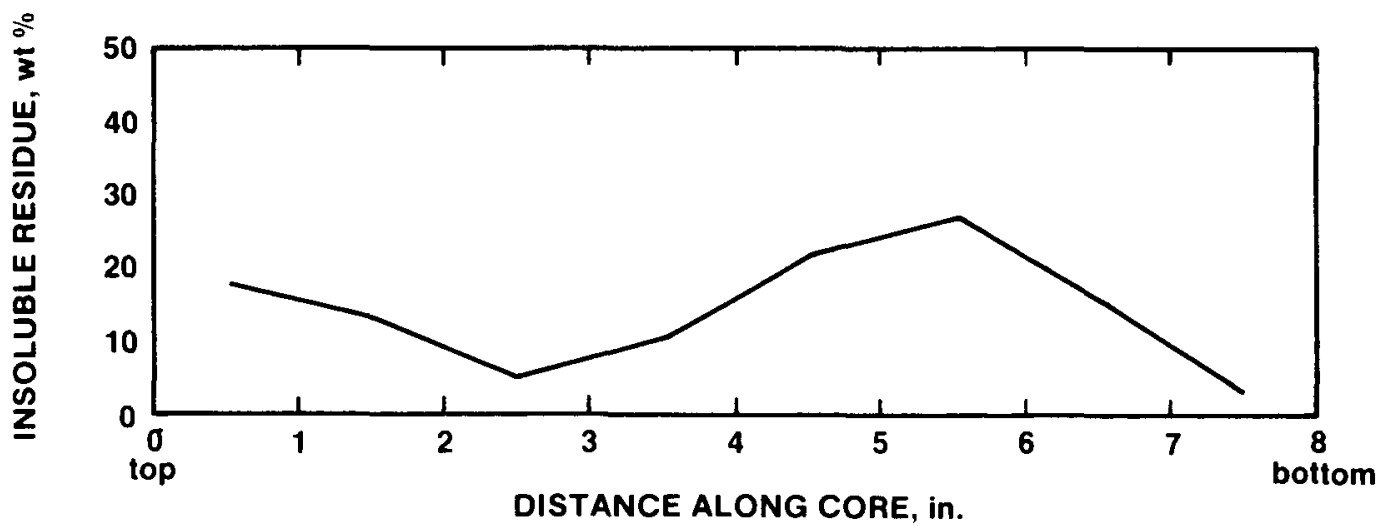

(c)

Figure 3. Comparison of three different methods of detection of non- $\mathrm{NaCl}$ mineralogy by using surplus core from the WIPP facility horizon: (a) gamma-beam densitometry, (b) x-radiography, and (c) conventional dissolution technique. 


\section{Discussion}

The primary purpose of this study was to examine closely the non- $\mathrm{NaCl}$ constituents of halite in the lower Salado Formation as a means of characterizing the lithology of the WIPP host rock in terms of abundance, distribution, and identification of trace mineral components.

By way of addressing the first of these, the data presented in Tables 1 and 3 are consistent with similar analyses performed for the SPDV program. For the samples analyzed in the study reported here, weight percents of water-insoluble residues ranged from 0.05 to $87.08 \mathrm{wt} \%$. For the EDTA-insoluble residues, weight percents ranged from 0.001 to $5.68 \mathrm{wt} \%$ of the total weights. The mean values for the water- and EDTA-insoluble residues are $5.56 \mathrm{wt} \%$ and $0.64 \mathrm{wt} \%$, respectively. The occasional excursions from the average numbers were attributed to unusually clay-rich layers or seams and/or to distinct anhydrite units. Linear statistics for these data are found in Table 5.

One of the most significant conclusions gained from the SPDV work is that the measurements of the non- $\mathrm{NaCl}$ mineralogy, as weight percents, are smaller by at least an order of magnitude than previous estimates made by visual observations. Many of the WIPP lithologic logs that predate the SPDV mineralogy study report the presence of polyhalite and clays in amounts ranging from 30 to $50 \mathrm{wt} \%$ or more. The SPDV results show that only a very small amount of non- $\mathrm{NaCl}$ material can impart such color and opacity to the salt so as to create the visual impression of a much larger quantity. For this reason, it was decided to put portions of the samples used in this study together with the data from the water- and EDTAinsoluble residue analyses into a reference collection in order to better "calibrate" visual estimates and therefore enable visual core descriptions to be made more quantitatively.

It is much more difficult, however, to describe and quantify the distribution of non- $\mathrm{NaCl}$ minerals dispersed in a halite core. For example, consider a halite sample weighing $500 \mathrm{~g}$ and containing $5 \%$ clay by weight. The analytical techniques used in this study (the results of which are shown in Tables 1 and 3) do not distinguish the distribution of this amount of clay in this particular sample interval. It could be present as fine particles evenly disseminated throughout the halite; it may occur as intergranular in-fillings or as large blebs; it may be present as a single discrete layer or seam in otherwise "clean" halite; or it may be some combination of all of these. While clay seams or layers are, for the most part, visually conspicuous enough to be noted as such in the lithologic logs, the distribution of trace minerals in most halitic core is obscure enough that an accurate characterization would best be obtained by detailed examination of many thin sections. This approach is out of the question, given the volume of core required for this study and time constraints on the analyst. An attempt was therefore made to develop a technique that would be both rapid and nondestructive, yielding an accurate determination of the distribution of trace minerals and at the same time preserving the core intact for future use. Variations in gamma-beam densitometry as a function of mineralogy are slight. Measurements of film density of the $\mathbf{x}$ radiographs appear to be significantly more sensitive and to parallel the results of the mineralogical determinations made by using the conventional technique described in this report.

As shown in Table 2, the water-insoluble mineralogy of these samples consists of quartz, magnesite, anhydrite, gypsum, polyhalite, alkali feldspar, and clays. Because of the complexity of the analytical process required to distinguish clay mineral species (separation of the clay fraction, heat treatment, exposure to ethylene glycol, etc), we report here only the basal planar spacings observed in the diffractograms of these samples. Major peaks belonging to clay minerals were observed at $14 \AA, 10 \AA, 9.3 \AA$, and $7 \AA$. Detailed clay mineralogical analyses on these and other WIPP samples are in progress; results will be presented in a later report. The EDTA-insoluble mineralogy (Table 4) consists entirely of quartz and clays except for a few samples showing traces of anhydrite, magnesite, and polyhalite, where EDTA digestion was obviously incomplete. Again, as described in the preceding paragraph, the clay minerals have not been identified as particular individual species, but only by the presence or absence of major peaks.

Most of the quartz ( $>90 \%$, based on binocular microscope inspection of the samples in which it was found) appears to consist of well-developed, doubly terminated euhedral crystals. This morphology is highly suggestive of an authigenic origin. First observed in the SPDV samples, these quartz crystals appear to be associated exclusively with clay-bearing or "argillaceous" halite, as described in the lithologic logs. This association implies an origin of authigenic quartz through diagenetic alteration of the clay minerals; one possible mechanism is (from Siever, 1962):

$$
\text { montmorillonite } \longrightarrow \text { illite }+\mathrm{SiO}_{2}
$$

The authigenic morphologies (Figures 2(a) - (c)) together with the textural relationships as seen in thin section (Figure 2(d)) also suggest that clay diagenesis and quartz precipitation preceded halite recrystallization. 
Table 5. Statistics on Weight-Percent Data

\begin{tabular}{|c|c|c|c|}
\hline \multicolumn{2}{|c|}{ Water-Insoluble Residues } & \multicolumn{2}{|c|}{ EDTA-Insoluble Residues } \\
\hline $\mathbf{M}$ & $0.45000 \mathrm{D}+02$ & $\mathbf{M}$ & $0.42000 \mathrm{D}+02$ \\
\hline Mean & $0.55620 \mathrm{D}+01$ & Mean & $0.63524 \mathrm{D}+00$ \\
\hline Std. Dev. & $0.14567 \mathrm{D}+02$ & Std. Dev. & $0.10344 \mathrm{D}+01$ \\
\hline Variance & $0.21218 \mathrm{D}+03$ & Variance & $0.10701 \mathrm{D}+01$ \\
\hline Max. X & $0.87080 \mathrm{D}+02$ & Max. X & $0.56600 \mathrm{D}+01$ \\
\hline Min. X & $0.50000 \mathrm{D}-01$ & Min. $\mathbf{X}$ & $0.10000 \mathrm{D}-02$ \\
\hline Range & $0.07030 \mathrm{D}+02$ & Range & $0.56790 \mathrm{D}+01$ \\
\hline Sum. X & $0.25029 \mathrm{D}+03$ & Sum. X & $0.26680 \mathrm{D}+02$ \\
\hline Sum. X Square & $0.10728 \mathrm{D}+05$ & Sum. X Square & $0.60821 \mathrm{D}+02$ \\
\hline Correction Term & $0.13921 \mathrm{D}+04$ & Correction Term & $0.16948 \mathrm{D}+02$ \\
\hline Sum. Small X Square & $0.93361 \mathrm{D}+04$ & Sum. Small X Square & $0.43873 \mathrm{D}+02$ \\
\hline Std. Dev. (Mean) & $0.21715 \mathrm{D}+01$ & Std. Dev. (Mean) & $0.15962 \mathrm{D}+00$ \\
\hline Variance (Mean) & $0.47152 \mathrm{D}+01$ & Variance (Mean) & $0.25478 \mathrm{D}-01$ \\
\hline Normality Test & & Normality Test & \\
\hline Mean Dev. & $0.75722 \mathrm{D}+01$ & Mean Dev. & $0.64367 \mathrm{D}+00$ \\
\hline Third Moment & $0.12952 \mathrm{D}+05$ & Third Moment & $0.34221 \mathrm{D}+01$ \\
\hline Fourth Moment & $0.10072 \mathrm{D}+07$ & Fourth Moment & $0.16297 \mathrm{D}+02$ \\
\hline A & $0.52571 \mathrm{D}+00$ & A & $0.62978 \mathrm{D}+00$ \\
\hline Sort B Sub1 & $0.43342 \mathrm{D}+01$ & Sort B Sub1 & $0.32053 \mathrm{D}+01$ \\
\hline B Sub2 & $0.23399 \mathrm{D}+02$ & B Sub2 & $0.14935 \mathrm{D}+02$ \\
\hline D-Test Statistic & $0.98294 \mathrm{D}+01$ & D-Test Statistic & $0.49859 \mathrm{D}+01$ \\
\hline
\end{tabular}

A simple mass balance calculation (Stein, 1984) clearly indicates that the volume of authigenic quartz present in these halite samples is, on the average, greater by almost two orders of magnitude than that which could have been produced by simple evaporation of seawater alone. Further studies of authigenic silicate formation and clay diagenesis are in progress. In addition to the quartz, other authigenic minerals may be present; authigenic feldspars and pyrite and possibly a zeolite have been identified by the author in thin-section, $x$-ray diffraction, and SEM work on some of the samples in this study. Because these results are preliminary, further details are not included here but will be reported on at a later date.

Figures 4 and 5 illustrate the relationship between weight percents of water- and EDTA-insoluble residues and lithology, as seen in the cores from which these samples were taken. No obvious correlation exists between the non- $\mathrm{NaCl}$ mineralogy and distance from the repository in either the up or down direction. However, these figures indicate that samples from anhydrite-bearing units contain the largest amounts of insoluble residues. Perhaps not surprisingly, samples from the visually designated "clean" halites contain the least. Moreover, in Figures 4 and 5, two lines are used for each sample interval to represent weight percents of water- and EDTA-insoluble residues. The larger the difference between these two lines in any one sample, the greater the relative abundance of the EDTA-soluble component (mainly the sulfate minerals polyhalite and anhydrite). This is clearly seen in samples such as FH-231, FH-236, and FH-240, taken from distinct anhydrite units in core RM-1 at depths of 7.1 to $7.3 \mathrm{ft}, 14$ to $14.45 \mathrm{ft}$, and 36.9 to $37.6 \mathrm{ft}$, respectively. Conversely, where the difference between each pair of lines is small (for example, FH-239, FH-242, or FH-217 through FH-224), the amounts of water- and EDTA-insoluble residues are nearly equal and thus composed primarily of insoluble silicate residues (quartz and clays) as is typically seen in the zones of argillaceous halite.

It is beyond the scope of this report to discuss the effects of trace mineralogy in WIPP salt on material properties or on creep behavior in rock salt. It is intended that the data reported here will be used to further modify the structural computations as discussed in Krieg et al (1980). This report is intended for use as a supplement to Krieg et al (1982) and Krieg (1984), by providing a more complete reference stratigraphy that includes detailed analyses of the halite mineralogy. 
CORE: RM-1

DIRECTION OF DRILLING: VERTICAL UP

LOCATION: TEST ROOM 4 (ROOF)

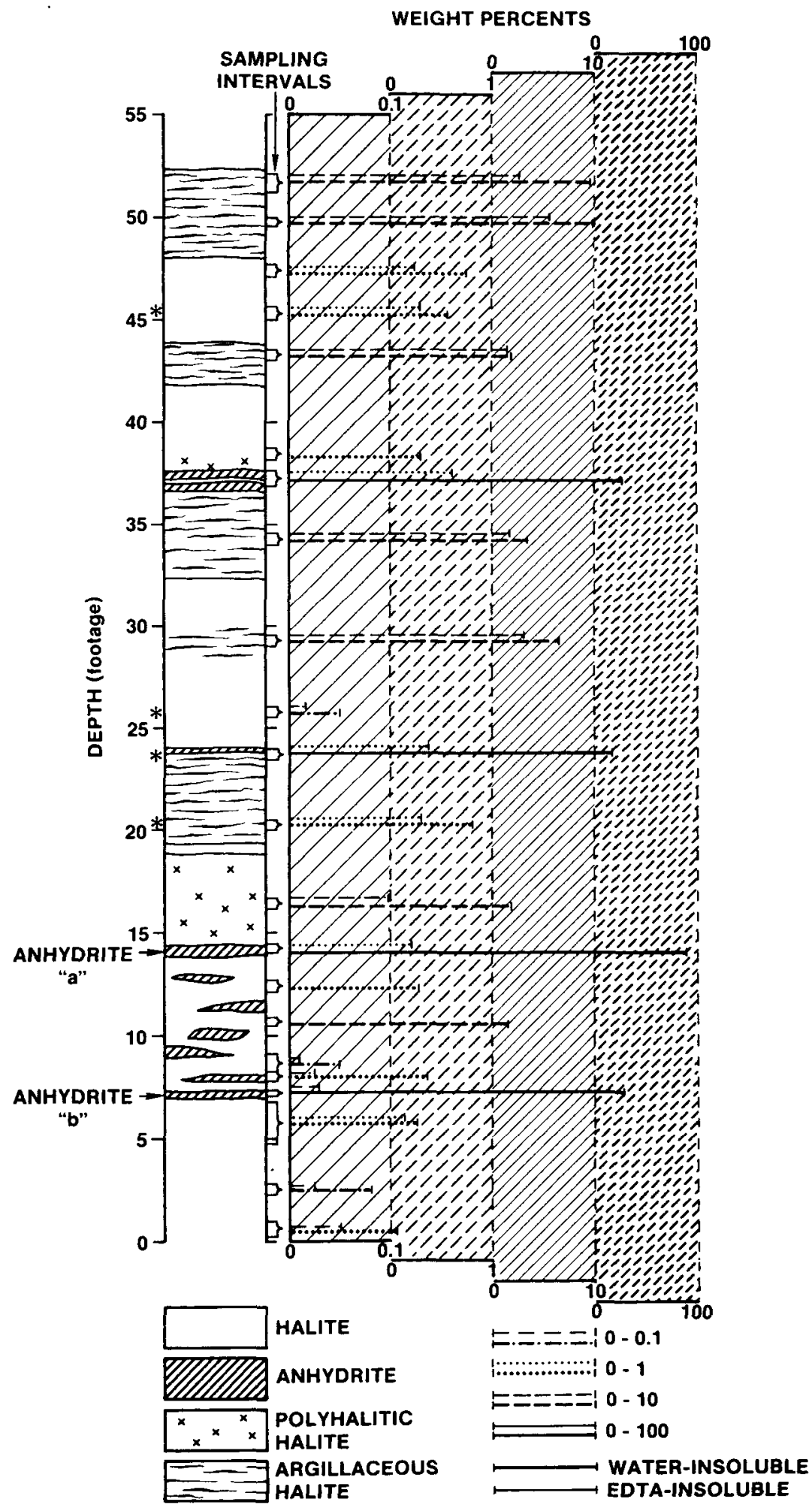

* SAMPLES ARE FROM RM-7

Figure 4. Core RM-1, showing lithologies and amounts of water- and EDTA-insoluble residues. (RM-7 samples are from another core, taken in the up direction, in close proximity to RM-1 (see Figure 1).) 
CORE: RM-3

DIRECTION OF DRILLING: VERTICAL DOWN LOCATION: TEST ROOM 4 (FLOOR)

\section{WEIGHT PERCENTS}

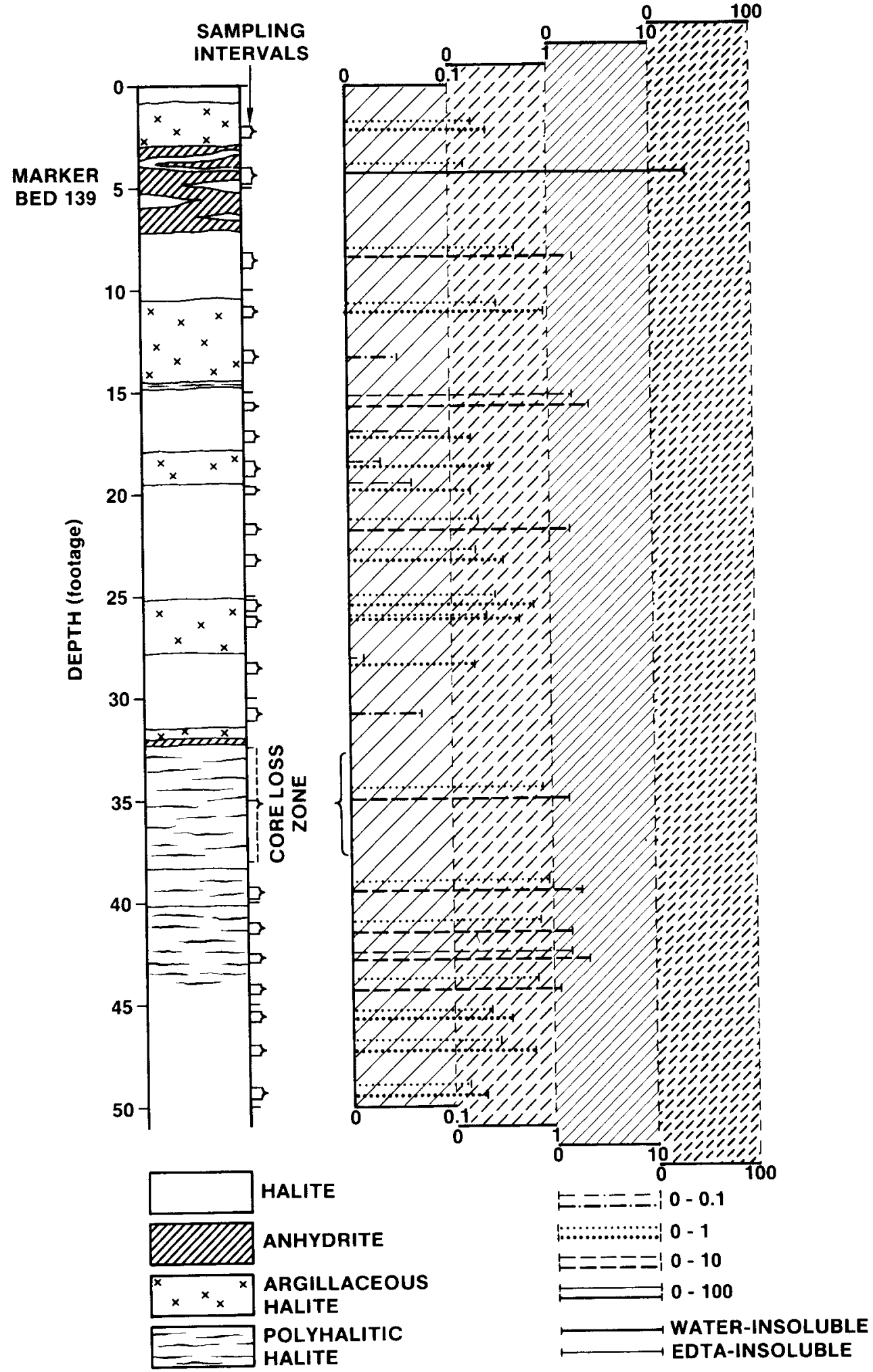

Figure 5. Core RM-3, showing lithologies and amounts of water- and EDTA-insoluble residues. 


\section{Conclusions}

In summary, we report here the quantities, distribution, and mineralogical species of the non- $\mathrm{NaCl}$ components of halite and anydrites in the immediate vicinity (e.g., within 100 vertical feet) of the WIPP facility horizon. These components, as determined by $\mathrm{x}$-ray diffraction, consist of quartz, anhydrite, gypsum, magnesite, polyhalite, and clays, with traces of alkali feldspar and possible zeolites. The quartz is primarily authigenic and is probably derived from alteration of the clay minerals. Textural relations indicate that this alteration and precipitation of the authigentic quartz either preceded or perhaps occurred simultaneously with halite recrystallization.

The results of the analyses presented herein confirm previous conclusions regarding discrepancies between visual estimates of mineral impurities in WIPP core and accurate measurements, as obtained by the precedure defined during the SPDV investigation. It has been shown that visual estimates of trace minerals may be too high by as much as an order of magnitude. WIPP salt contains, on the average, $<5 \mathrm{wt} \%$ mineral impurities, except in areas of well-defined anhydrite or clay bands or layers. These impurities occur as either finely divided particles dispersed throughout the halite, as intergranular coatings, or as discrete blebs, lenses, laminae, or seams.

The analytical procedure used to produce the results reported here is time-consuming and provides no detailed information as to the distribution of non$\mathrm{NaCl}$ minerals. Alternative methods of sample analysis are being investigated. It appears that $\mathbf{x}$-radiography of halite core is rapid, nondestructive, and accurately reflects mineral impurities in the salt. More work is necessary before this technique can be considered a quantitative tool for this type of examination. However, the data obtained from the samples analyzed in this study will be used as points for calibration.

\section{References}

M. W. Bodine, Jr., and T. H. Fernalld, "EDTA Dissolution of Gypsum, Anhydrite, and $\mathrm{Ca}-\mathrm{Mg}$ Carbonates," J Sed Petrology 43:4, 1152-1156 (1973).

Bechtel National, Inc., for US Dept. of Energy, Quarterly Geotechnical Field Data Report, Section B.O: Test Rooms; WIPP-DOE-199 (May 1985).

R. D. Krieg, H. S. Morgan, and T. O. Hunter, Second Benchmark Problem for WIPP Structural Computations, SAND80-1331 (Albuquerque, NM: Sandia National Laboratories, December 1980).

Memo, R. D. Krieg, D. Powers, and R. Price of Sandia National Laboratories (SNL), to D. E. Munson of SNL, "Proposed September '82 WIPP stratigraphy," September 20, 1982.

R. D. Krieg, Reference Stratigraphy and Rock Properties for the Waste Isolation Pilot Plant (WIPP) Project, SAND83-1908 (Albuquerque, NM: Sandia National Laboratories, January 1984).

Memo, D. C. Reda and G. R. Hadley of SNL to C. L. Stein of SNL, "Salt Core Characterization Via Gamma-Beam Attenuation Measurements," September 9,1983 .

R. Siever, "Silica Solubility, $0^{\circ}-200^{\circ} \mathrm{C}$, and the Diagenesis of Siliceous Sediments," J Geol 70, pp 127 150 (1962).

C. L. Stein, Supporting Document 11: "Mineralogical Content of Interval Strata"; Supporting Document 12: "Location and Characterization of Interbedded Materials," in Results of Site Validation Experiments, vol. 2, Supporting Document 5-14. Waste Isolation Pilot Plant, TME 3177 (1983).

C. L. Stein, "Authigenic Quartz in Halite from the Delaware Basin., Southeastern New Mexico (submitted to $J$ Geol, August 1984). 


\section{Appendix A}

Core: RM-1

\section{Lithologic Logs}

Direction of drilling: Vertical up

Location: Test Room 4 (roof)

Mine Coordinates: N1364 W631 approx.

Depth of Borehole: $52.1 \mathrm{ft}$

Logged by: J. E. Gallerani

Elev. above

Ceiling (ft)

\begin{tabular}{cc}
\hline From & To \\
\hline 0 & 7.05
\end{tabular}

$7.2 \quad 13.9$

$13.9 \quad 14.4$

$14.44 \quad 18.8$
Halite: clear to medium reddishorange to light gray, coarsely crystalline, hard. Fine to medium crystalline at 6 to $7.05 \mathrm{ft}$. Trace $(<1 / 2 \%)$ polyhalite. Trace $(<1 \%)$ gray clay.

$7.05 \quad 7.2 \quad$ Anhydrite (anhydrite " $b$ "): very light gray to medium gray, microcrystalline; hard. Some patches of halite within. Trace gray clay at $7.05 \mathrm{ft}$. Irregular upper surface at $7.2 \mathrm{ft}$.

Halite: clear to medium reddishorange, medium to coarsely crystalline, hard. White anhydrite stringers and laminae found within core. Beginning at $12.3 \mathrm{ft}$ trace gray clay $(<1 \%)$. Core medium grading to fine-medium crystalline toward anhydrite.

Anhydrite: very light gray to medium gray, microcrystalline, hard. Scattered halite. Trace gray clay at $13.9 \mathrm{ft}$. Upper contact at $14.4 \mathrm{ft}$ is irregular, tightly welded.

Polyhalitic halite: clear to medium reddish-brown-orange, coarsely crystalline, moderately hard to hard. Contains blebs and patches of polyhalite ( $1 \%$ to $5 \%$ ), locally $>5 \%$.
Elev. above

Ceiling (ft)

\begin{tabular}{cc}
\hline From & To \\
\hline 18.8 & 19.3
\end{tabular}

19.3 24.05 Argillaceous halite: clear to medium grayish-brown, fine to coarsely crystalline, medium hard to hard. Contains gray and brown clay, generally $<2 \%$. Trace medium reddish-orange color. Gray anhydrite layer at 23.85 to $24 \mathrm{ft}$, thin gray lamina immediately beneath.

$24.05 \quad 32.4 \quad$ Halite: clear, coarsely crystalline, hard. Several irregular white patches at 25 to $25.7 \mathrm{ft}$. Clear to medium brown from 28.3 to $29.5 \mathrm{ft}$; brown clay ( $1 \%$ to $2 \%$ ) breaks at $29 \mathrm{ft}$ and $29.25 \mathrm{ft}$.

$32.4 \quad 36.65 \quad$ Argillaceous halite: clear to medium reddish-brown and grayishbrown, coarsely crystalline, medium hard to hard. Dispersed argillaceous, predominantly brown. Avg. $<1 \%$ to $3 \%$, locally $>5 \%$.

$36.65 \quad 37.6 \quad$ Anhydrite: very light gray to medium gray, microcrystalline hard anhydrite with irregular zone of halite at $\sim 37.15$ to $37.35 \mathrm{ft}$. Upper contact irregular, tightly welded. Gray clay at $36.7 \mathrm{ft}$. 
Elev. above

Ceiling (ft)

From To

$37.6 \quad 41.8$

$41.8 \quad 43.9$

$43.9 \quad 48$

48

52.1
Halite: clear to medium reddishorange, coarsely crystalline, hard. Contains $<1 \%$ polyhalite (dispersed reddish-orange color). Core contains highest \% polyhalite 37.6 to $38.2 \mathrm{ft}$, scattered white (magnesite) stringers.

Argillaceous halite: clear to medium brown, coarsely crystalline with some fine, medium hard to hard. Predominantly brown argillaceous $1 \%$ to $3 \%$, locally up to $5 \%$.

Halite: clear to medium brown, fine to coarsely crystalline, medium hard. Trace $(<1 \%)$ argillaceous and polyhalite.

Argillaceous halite: clear to medium brown, medium with some fine to coarsely crystalline, medium hard to hard. Brown argillaceous $(1 \%$ to $5 \%$, avg. $1 \%$ to $2 \%$. Clay break at $52.1 \mathrm{ft} .5 \%$ to $>10 \%$ brown clay at 49.6 to 50.2 ft. Trace $(<1 \%)$ polyhalite.

Core: RM-4

Direction of drilling: Vertical down

Location: Test Room 4 (floor)

Mine Coordinates: N1362.6 W627.5

Depth of Borehole: $49.5 \mathrm{ft}$

Logged by: J. E. Gallerani

Depth below

floor (ft)

From To

$\begin{array}{ll}0 & 2.7\end{array}$

Halite: clear to medium brown, medium to coarsely crystalline, medium hard to hard. Trace $(<1 \%)$ polyhalite and gray clay.
$6.85 \quad 10.3$

Depth below

floor (ft)

\begin{tabular}{cc}
\hline From & To \\
\hline 2.7 & 6.85
\end{tabular}

Anhydrite (MB-139): mixture of medium reddish-orange polyhalite, polyhalitic halite and anhydrite from 2.7 to $4.2 \mathrm{ft}$. Coarsely crystalline polyhalitic halite mixed with polyhalitic and microcrystalline anhydrite, approx. $40 \%$ to $60 \%$. Grades to higher $\%$ anhydrite 4.2 to $5.6 \mathrm{ft}$. From 5.6 to $6.85 \mathrm{ft}$ is anhydrite. Very light gray to white microcrystalline, laminated anhydrite mixed with $10 \%$ to $30 \%$ polyhalite and polyhalitic halite, hard. Core broken in small pieces at 4.4 to 4.6 $\mathrm{ft}$. Trace gray clay at $6.85 \mathrm{ft}$.

Halite: clear to grayish to medium reddish-orange, medium to coarsely crystalline, hard. Gray clay $<1 \%$, scattered clay breaks. Trace $(<1 \%)$ polyhalite.

$10.3 \quad 14.1 \quad$ Polyhalitic halite: clear to medium reddish-orange, coarsely crystalline, hard. Polyhalite $<1 \%$ to $3 \%$, locally $>3 \%$. Scattered gray clay breaks to $11.3 \mathrm{ft}$.

14.1 $16.6 \quad$ Halite: clear to light-gray to medium reddish-orange, medium to coarsely crystalline, hard. Trace $(<1 \%)$ gray clay. Parting at $14.3 \mathrm{ft}$. Scattered clay breaks, $<1 \%$ polyhalitic.

16.6 $17.7 \quad$ Halite: clear with trace of medium reddish-orange, coarsely crystalline, hard. Trace $(<1 \%)$ polyhalite.

$17.7 \quad 19.9 \quad$ Halite: clear to medium reddishorange-brown, coarsely crystalline, hard. Generally $<1 \%$ polyhalite with local zones to $3 \%$. From 18.4 to $19.6 \mathrm{ft}$, up to $5 \%$ polyhalite.

$19.926 .5 \quad$ Halite: clear mottled with medium reddish-orange and light gray, medium to coarsely crystalline, hard. Gray clay $<1 \%$. $<1 \%$ polyhalite with local zones to $2 \%$. 
Depth below

floor $(\mathrm{ft})$

\begin{tabular}{lc}
\hline From & To \\
\hline 26.5 & 32.05
\end{tabular}

Halite: clear to medium reddishorange-brown, coarsely crystalline, hard, polyhalitic. Up to $5 \%$ polyhalite from $\sim 26.5$ to $27.5 \mathrm{ft}$ decreasing to avg $<1 \%$ polyhalite below $29.5 \mathrm{ft}$. Mostly anhydrite at 31.45 to $31.65 \mathrm{ft}$. Clear halite 30.65 to $31.45 \mathrm{ft}$.

$32.4 \quad 39.5 \quad$ Halite: clear to medium reddishorange and medium-dark gray, medium to coarsely crystalline, hard. Trace $(<1 \%)$ gray clay and trace $(<1 \%)$ scattered polyhalite blebs. Core broken up in very small pieces (gravel-size up to 1 in.) at 33.4 to $33.75 \mathrm{ft}$.

$39.543 \quad$ Halite: clear to medium brown, medium to coarsely crystalline, medium hard to hard. Contains $<1 \%$ to $3 \%$ predominantly brown argillaceous, clay breaks scattered within. Trace $(<1 / 2 \%)$ polyhalite dispersed throughout.

$43 \quad 50.2$
Halite: clear mottled with traces $(<1 \%)$ of gray clay and medium reddish-orange polyhalite blebs. Medium to coarsely crystalline, hard. Up to $3 \%$ gray argillaceous at 48.55 to $49.1 \mathrm{ft}$.

Core: RM-3

Direction of drilling: Vertical down

Location: Test Room 4 (floor)

Mine Coordinates: N1361 W631 approx.

Depth of Borehole: $51.05 \mathrm{ft}$

$19.5 \quad 32$

Logged by: J. E. Gallerani

Depth below

floor (ft)

\begin{tabular}{cc}
\hline From & To \\
\hline 0 & 0.9
\end{tabular}

Halite: clear, coarsely crystalline, hard. Trace $(<1 / 2 \%)$ polyhalite blebs and gray clay.

$0.93 \quad$ Polyhalitic halite: clear to medium reddish-orange, coarsely crystalline hard. $<1 \%$ polyhalite increasing to $\sim 3 \%$ to $4 \%$ toward lower part of section.

Depth below

floor (ft)

\begin{tabular}{cc}
\hline From & To \\
\hline 3 & 7.2
\end{tabular}

$7.2 \quad 10.45$

$10.45 \quad 14.8$

$14.8 \quad 16.5$

$16.5 \quad 17.9$

$17.9 \quad 19.5$ 
Depth below

floor (ft)

From To

$32.0 \quad 32.1$

$32.1 \quad 38.3$

$38.3 \quad 51.05$
Anhydrite: very light gray to light-gray anhydrite mixed with some halite. Microcrystalline, hard. Trace gray clay at $32.1 \mathrm{ft}$. Core loss from 30.75 to $35.75 \mathrm{ft}$. Depth of anhydrite based on boring RM-2.

Halite: clear with some medium reddish-orange and light gray. Medium to coarsely crystalline, medium hard to hard. Trace $(<1 \%)$ gray clay and polyhalite. Core loss in this section.

Halite: clear to light gray mottled with medium reddishorange polyhalite. Coarsely crystalline, hard. Avg $<1 \%$ to $4 \%$ gray clay. Clay breaks irregular and low angle, commonly scattered in core to $\sim 44 \mathrm{ft}$. $<1 \%$ clay from $44 \mathrm{ft}$ to bottom of hole. $<1 \%$ polyhalite average with $1 \%$ to $2 \%$ polyhalite 38.3 to $40.15 \mathrm{ft}$. 


\section{Appendix B}

\section{Description of Core Samples Used In This Study}

\section{Split Core Samples for Geochemistry Analysis}

\begin{tabular}{|c|c|c|c|c|}
\hline Sample No. & Hole No. & \multicolumn{2}{|c|}{ Depth Interval (ft) } & \multirow[t]{2}{*}{ Sample Description } \\
\hline & & From & To & \\
\hline FH-201 & RM-3 & 2 & 2.5 & Clear with trace polyhalite \\
\hline FH-202 & RM-3 & 4 & 4.7 & Polyhalitic halite \\
\hline FH-203 & RM-3 & 8.3 & 9 & $\begin{array}{l}8.3 \text { to } 8.5 \mathrm{ft} \text { - mixed clay/polyhalite } \\
8.5 \text { to } 9 \mathrm{ft} \text { - clear }\end{array}$ \\
\hline FH-204 & RM-3 & 10.8 & 11.3 & Clear, trace polyhalite (5 pieces) \\
\hline FH-205 & RM-3 & 13 & 13.55 & Polyhalitic (4 pieces) \\
\hline FH-206 & RM-3 & 15.55 & 15.85 & Mixed clay/polyhalite \\
\hline FH-207 & RM-3 & 16.9 & 17.45 & Clear, coarsely crystalline, trace polyhalite \\
\hline FH-208 & RM-3 & 18.4 & 19.1 & Polyhalitic ( 3 pieces) \\
\hline FH-209 & $\mathrm{RM}-3$ & 19.65 & 20.05 & Polyhalitic (3 pieces) \\
\hline FH-210 & $\mathrm{RM}-3$ & 21.5 & 22 & Clear mottled with polyhalite \\
\hline FH-211 & RM-3 & 23 & 23.5 & Same as above \\
\hline FH-212 & RM-3 & 25.1 & 25.7 & Clear to mod. reddish-orange, trace polyhalite \\
\hline FH-213 & RM-3 & 26 & 26.5 & Clear to mod. reddish-orange, trace polyhalite \\
\hline FH-214 & $\mathrm{RM}-3$ & 28.25 & 28.85 & Same as above with some horizontal fractures \\
\hline FH-215 & RM-3 & 30.5 & 31.05 & Clear, coarsely crystalline, very little polyhalite \\
\hline \multicolumn{3}{|c|}{ (Core loss zone) } & $\begin{array}{l}38 \\
\text { one) }\end{array}$ & Clear, trace gray clay, polyhalite \\
\hline FH-217 & RM-3 & 39.25 & 39.85 & Grayish-brown mixed clay/polyhalite \\
\hline FH-218 & $\mathrm{RM}-3$ & 41 & 41.5 & $\begin{array}{l}\text { Mixed clay/polyhalite, coarsely crystalline, very little } \\
\text { polyhalite }\end{array}$ \\
\hline FH-219 & $\mathrm{RM}-3$ & 42.5 & 43 & $\begin{array}{l}\text { Mixed clay/polyhalite, medium coarsely crystalline, very } \\
\text { little polyhalite }\end{array}$ \\
\hline FH-220 & $\mathrm{RM}-3$ & 44 & 44.5 & Mixed clay/polyhalite, coarsely crystalline \\
\hline FH-221 & RM-3 & 45.3 & 45.85 & Clear, coarsely crystalline \\
\hline FH-222 & RM-3 & 47 & 47.5 & Clear, trace gray clay \\
\hline FH-223 & RM-3 & 49.05 & 49.55 & Clear, trace gray clay/polyhalite \\
\hline FH-224 & RM-3 & 4 & 4.5 & Medium reddish-orange polyhalite/anhydrite \\
\hline
\end{tabular}

Core Samples for Geomechanical Testing

\begin{tabular}{|c|c|c|c|c|}
\hline FH-225 & $\mathrm{RM}-4$ & 40.75 & 42.5 & Mixed clay/polyhalite \\
\hline FH-226 & RM-4 & 42.5 & 44 & Mixed clay/polyhalite \\
\hline FH-227 & RM-5 & 39.05 & 41.6 & Mixed clay/polyhalite \\
\hline FH-228 & RM-1 & 0.4 & 0.9 & $\begin{array}{l}\text { Halite, clear to medium reddish-brown to light gray, } \\
\text { coarsely, some fine to medium crystalline. Trace polyha- } \\
\text { lite and clay }\end{array}$ \\
\hline FH-229 & RM-1 & 2.3 & 2.8 & Same as above \\
\hline FH-230 & RM-1 & 4.75 & 6.75 & Same as above \\
\hline FH-231 & RM-1 & 7.1 & 7.3 & Anhydrite "b" with halite 7.2 to $7.3 \mathrm{ft}$ \\
\hline
\end{tabular}




\begin{tabular}{|c|c|c|c|c|}
\hline & & From & To & \\
\hline FH-232 & RM-1 & 7.75 & 8.15 & $\begin{array}{l}\text { Halite, clear to medium reddish-orange, medium to } \\
\text { coarsely crystalline, white anhydrite stringers }\end{array}$ \\
\hline FH-233 & RM-1 & 8.15 & 9.1 & Same as above \\
\hline FH-234 & RM-1 & 10.5 & 10.9 & Same as above \\
\hline FH-235 & RM-1 & 12.15 & 12.6 & Same with trace gray clay \\
\hline FH-236 & RM-1 & 14 & 14.45 & Anhydrite "a" \\
\hline FH-237 & RM-1 & 16.1 & 16.6 & Polyhalite halite \\
\hline FH-238 & RM-1 & 29 & 29.5 & Halite with brown clay, coarsely crystalline \\
\hline FH-239 & RM-1 & 34.05 & 34.5 & Argillaceous halite \\
\hline FH-240 & RM-1 & 36.9 & 37.6 & Anhydrite with some halite \\
\hline FH-241 & RM-1 & 38.2 & 38.7 & Halite with trace polyhalite, magnesite stringers \\
\hline FH-242 & RM-1 & 43.05 & 43.55 & Argillaceous halite \\
\hline FH-243 & RM-1 & 47.2 & 47.7 & Halite, trace polyhalite and clay \\
\hline FH-244 & RM-1 & 49.65 & 50 & Argillaceous halite \\
\hline FH-245 & RM-1 & 51.3 & 52.1 & Argillaceous halite, break at $52.1 \mathrm{ft}$ \\
\hline FH-246 & RM-7 & 20.05 & 20.45 & Halite, trace of clay and polyhalite \\
\hline FH-247 & RM-7 & 23.45 & 23.95 & Halite with gray anhydrite, trace clay \\
\hline FH-248 & RM-7 & 25.5 & 26 & Halite - clear, coarsely crystalline \\
\hline FH-249 & RM-7 & 45 & 45.65 & Halite, trace brown clay, coarsely crystalline \\
\hline
\end{tabular}




\section{DISTRIBUTION:}

US Department of Energy, Headquarters (2) Office of Nuclear Waste Management

Attn: A. Follett, Project Coordinator (WIPP) R. Stein

Washington, DC 20545

US Department of Energy (2)

Albuquerque Operations Office

Attn: G. C. Romatowski

D. G. Jackson, Dir, Public Affairs Div

PO Box 5400

Albuquerque, NM 87185

US Department of Energy (6)

Attn: W. R. Cooper

Carlsbad WIPP Project Office (2)

A. Hunt, WPO (Carlsbad) (4)

PO Box 3090

Carlsbad, NM 88221

US Department of Energy

Carlsbad WIPP Project Office

Room 113, Federal Bldg

Carlsbad, NM 88220

US Department of Energy, NPO (2)

Office of Nuclear Waste Isolation

Attn: Jeff $O$. Neff

R. Wunderlich

505 King Ave

Columbus, OH 43201

US Department of Energy

Richland Operations Office

Nuclear Fuel Cycle and Production Div

Attn: R. E. Gerton

PO Box 500

Richland, WA 99352

US Department of Energy

Research and Tech Support Div

Attn: D .E. Large

PO Box E

Oak Ridge, TN 37830

US Department of Energy (2)

Division of Waste Products

Attn: G. H. Daly

J. E. Dieckhoner

Mail Stop B-107

Washington, DC 20545
US Department of Energy (2)

Idaho Operations Office

Nuclear Fuel Cycle Div

Attn: R. M. Nelson

J. Whitsett

550 Second St

Idaho Falls, ID 83401

US Department of Energy (4)

Savannah River Operations Office

Waste Management Project Office

Attn: J. R. Covell

D. Fulmer

S. Cowan

PO Box A

W. J. Brumley

Aiken, SC 29801

US Nuclear Regulatory Commission (3)

Division of Waste Management

Attn: Michael Bell

Hubart Miller

Jacob Philip

Mail Stop 697SS

Washington, DC 20555

US Nuclear Regulatory Commission

HLW Licensing Branch, Materials Section

Attn: F. R. Cook

MS 905 SS

Washington, DC 20555

Battelle Memorial Inst (17)

Project Management Div

Attn: W. Carbiener, General Manager (3)

S. Basham

D. E. Clark

S. Goldsmith

J. E. Hanley

P. Hoffman

H. R. Hume

H. N. Kalia

J. Kircher

S. Matthews

D. Moak

J. Moody

G. Raines

J. Treadwell

ONWI Library

505 King Ave

Columbus, OH 43201 
DISTRIBUTION (cont):

Battelle Pacific Northwest Labs (4)

Attn: D. J. Bradley

J. Relyea

R. P. Turcotte

R. E. Westerman

Battelle Blvd

Richland, WA 99352

Westinghouse Electric Corp (9)

Attn: P. Miskimin

V. Likar

L. Cole

V. DeJong

R. Gehrman

J. Johnson

J. W. Sadler

J. E. Stumbaugh

Library

PO Box 2078

Carlsbad, NM 88221

Bechtel, Inc (5)

Attn: E. Weber

H. Taylor

P. Frobenius

D. L. Wu

W. T. Li

45-11-B34

PO Box 3965

San Francisco, CA 94119

Oak Ridge National Lab (4)

Attn: R. E. Blanko

E. Bondietti

C. Claiborne

G. H. Jenks

PO Box Y

Oak Ridge, TN 37830

Oak Ridge National Lab

Attn: John O. Blomeke

PO Box X

Oak Ridge, TN 37830

US Geological Survey

Water Resources Div

Attn: John D. Bredehoeft,

Western Region Hydrologist

345 Middlefield Rd

Menlo Park, CA 94025
Dr. Karl P. Cohen

928 N California Ave

Palo Alto, CA 94303

Stanford University

National Acad. of Sci., WIPP Panel

Dept. of Geology

Attn: Konrad B. Krauskopf, Chairman

Palo Alto, CA 94305

Vanderbilt University

Dept. of Environmental and

Water Resources Engineering

Attn: Frank L. Parker, Vice Chm.

Nashville, TN 37235

University of Florida

Department of Material Sciences and Engineering

Attn: Fred M. Ernsberger, Adjunct Professor

Gainesville, FL 32611

Johns Hopkins University

Department of Earth Sciences

Attn: Hans P. Eugster

Baltimore, MD 21218

University of New Mexico

Department of Geology

Attn: Rodney C. Ewing

Albuquerque, NM 87131

University of Minnesota

Department of Geological Sciences

Attn: Charles Fairhurst

Minneapolis, MN 55455

University of Texas at Austin

Department of Geological Sciences

Attn: William R. Muehlberger

Austin, TX 78712

D'Arcy A. Shock

233 Virginia

Ponca City, OK 74601

National Academy of Sciences

Committee on Radioactive Waste Management

Attn: John T. Holloway, Senior Staff Officer

2101 Constitution Ave, NW

Washington, DC 20418 
DISTRIBUTION (cont):

Hobbs Public Library

Attn: Marcia Lewis, Librarian

509 N. Ship St

Hobbs, NM 88248

NM Inst of Mining/Tech

Martin Speere Memorial Library

Campus St

Socorro, NM 87810

New Mexico State Library

Attn: Ingrid Vollenhofer

PO Box 1629

Santa Fe, NM 87503

University of New Mexico

Zimmerman Library

Attn: Zanier Vivian

Albuquerque, NM 87131

WIPP Public Reading Room

Attn: Gwynn Schreiner

Atomic Museum, Kirtland AFB, East

Albuquerque, NM 87185

WIPP Public Reading Room

Carlsbad Municipal Library

Attn: Lee Hubbard, Head Librarian

$101 \mathrm{~S}$ Hallagueno St

Carlsbad, NM 88220

Thomas Brannigan Library

Attn: Don Dresp, Head Librarian

$106 \mathrm{~W}$ Hadley St

Las Cruces, NM 88001

Roswell Public Library

Attn: Nancy Langston

301 N Pennsylvania Ave

Roswell, NM 88201

State of New Mexico (2)

Environmental Evaluation Group

Attn: Robert H. Neill, Dir

PO Box 968

Santa Fe, NM 87503

NM Department of Energy and Minerals (2)

Attn: Larry Kehoe, Secretary

Kasey LaPlante, Librarian

PO Box 2770

Santa Fe, NM 87501
Argonne National Lab (5)

Attn: S. Fried

A. M. Friedman

D. Hambeley

N. Meldgin

M. Steindler

9700 S Cass Ave

Argonne, IL 60439

Brookhaven National Lab (2)

Attn: P. Colombo, Dept of Applied Sciences Cal Brewster, Bldg 830

Upton, NY 11973

Brookhaven National Lab

Associated Universities, Inc

Attn: Paul W. Levy, Senior Scientist

Upton, NY 11973

IT Corp (4)

Attn: P. Kelsall

R. McKinney

A. Moss

D. Shukla

Suite 306

2350 Alamo, SE

Albuquerque, NM 87106

E. I. Dupont de Nemours Co (4)

Attn: N. Bibler

E. J. Hennelly

M. J. Plodinec

G. G. Wicks

Savannah River Lab

Aiken, SC 29801

E. I. Dupont de Nemours Co

Attn: R. Baxter

Savannah River Plant

Aiken, SC 29801

Oak Ridge National Laboratory, Bldg. 2001

Ecological Sciences Information Center

Attn: C. S. Fore

PO Box X

Oak Ridge, TN 37830

Texas A\&M University

Center of Tectonophysics

Attn: John Handin

College Station, TX 77840 


\section{DISTRIBUTION (cont):}

J. F. T. Agapito Assoc, Inc Attn: Christopher St. John 715 Horizon Dr, Suite 340 Grand Junction, CO 81501

Science Applications, Inc

Attn: D. E. Maxwell

2450 Washington Ave, Suite 120

San Leandro, CA 94577

Los Alamos National Lab

Attn: B. Erdal, CNC-11

PO Box 1663

Los Alamos, NM 87545

Rockwell International (3)

Atomics International Div

Attn: M. J. Smith

W. W. Schultz

P. Salter

Rockwell Hanford Operations

PO Box 800

Richland, WA 99352

US Department of Interior

Geological Survey

Attn: E. Roedder

959 National Center

Reston, VA 22092

Serata Geomechanics

Attn: Dr. Shosei Serata

4124 Lakeside Dr

Richmond, CA 94806-1941

Systems, Science, and Software (2)

Attn: P. Lagus

Box 1620

E. Peterson

La Jolla, CA 92038

Titanium Metals Corp of America

Henderson Technical Lab

Attn: R. W. Schulz

PO Box 2128

Henderson, NV 89015
US Army Engineers (8)

Waterways Experiment Station

Attn: D. Ainsworth

J. Armstrong

J. Boa

A. Buck

K. Mather

C. Pace

L. Wakeley

D. Walley

PO Box 631

Vicksburg, MS 39180

University of Arizona

Department of Mining and Geological Engineering

Attn: J. J. K. Daemen

Tucson, AZ 85721

University of New Mexico

Geology Department

Attn: D. G. Brookins

Albuquerque, NM 87131

Cornell University

Department of Physics

Attn: Dr. R. O. Pohl

Clark Hall

Ithaca, NY 14853

Cornell University

Department of Mechanical

and Aerospace Engineering

Attn: Dr. Paul R. Dawson

254 Upson Hall

Ithaca, NY 14853

University of Minnesota

Department of Energy

and Materials Science

Attn: R. Oriani

151 Amundson Hall

421 Washington Ave, SE

Minneapolis, MN 55455

The Pennsylvania State University (2)

Materials Research Lab

Attn: Della Roy

Rustum Roy

University Park, PA 16802 


\section{DISTRIBUTION (cont):}

Princeton University

Dept of Civil Engineering

Attn: George Pinder

Princeton, NJ 08540

RE/SPEC, Inc. (4)

Attn: P. Gnirk

T. Pfeifle

R. Stickney

L. Van Sambeek

PO Box 725

Rapid City, SD 57701

RE/SPEC, Inc (2)

Attn: S. W. Key

D. B. Blankenship

PO Box 14984

Albuquerque, NM 87191

Rockwell International (2)

Rocky Flats Plant

Attn: W. S. Bennett

C. E. Wickland

Golden, CO 80401

US Geological Survey

Special Projects

Attn: R. Snyder

MS954, Box 25046

Denver Federal Center

Denver, CO 80255

US Geological Survey

PO Box 26659

Albuquerque, NM 87125

Woodward-Clyde Consultants (2)

Library Western Region

Attn: Anne T. Harrigan, Librarian

Charles Taylor

3 Embarcadero Center, Suite 700

San Francisco, CA 94111

Institut fur Tieflagerung (3)

Attn: K. Kuhn

N. Jockwer

H. Gies

Theodor-Heuss-Strasse 4

D-3300 Braunschweig

FEDERAL REPUBLIC OF GERMANY
Bundesanstalt fur Geowissenschaften und Rohstoffe Attn: Michael Langer

Postfach 510153

3000 Hannover 51

FEDERAL REPUBLIC OF GERMANY

Hahn-Mietner-Institut fur Kernforschung

Attn: Klaus Eckart Maass

Glienicker Strasse 100

1000 Berlin 39

FEDERAL REPUBLIC OF GERMANY

Bundesministerium fur Forschung und Technologie

Attn: Rolf-Peter Randl

Postfach 200706

5300 Bonn 2

FEDERAL REPUBLIC OF GERMANY

Physikalisch-Technische Bundesanstalt

Attn: Helmut Rothemeyer

Bundesanstalt 100

3300 Braunschweig

FEDERAL REPUBLIC OF GERMANY

Kernforschung Karlsruhe (3)

Attn: R. Koster

Reinhard Kraemer

K. D. Closs

Postfach 3640

7500 Karlsruhe

FEDERAL REPUBLIC OF GERMANY

Underground Storage of Radioactive Waste

Experimental Programs

Attn: Tuen Deboer, Manager

PO Box 1

1755 ZG Petten

THE NETHERLANDS

Svensk Karnbransleforsorjning AB

Project KBS

Karnbranslesakerhet

Attn: Fred Karlsson

Box 5864

10248 Stockholm

SWEDEN

Ontario Hydro Research Lab

Attn: Dr. D. K. Mukerjee

800 Kipling Ave

Toronto, Ontario

MBZ 554

CANADA 


\section{DISTRIBUTION (cont):}

$\begin{array}{ll}1510 & \text { J. W. Nunziato } \\ 1520 & \text { D. J. McCloskey } \\ 1521 & \text { R. D. Krieg } \\ 1521 & \text { H. S. Morgan } \\ 1540 & \text { W. C. Luth } \\ 1542 & \text { B. M. Butcher } \\ 1542 & \text { D. J. Holcomb } \\ 1542 & \text { L. W. Teufel } \\ 1542 & \text { W. R. Wawersik } \\ 1543 & \text { J. L. Krumhansl } \\ 1652 & \text { O. L. George, Jr. } \\ 1820 & \text { R. E. Whan } \\ 1830 & \text { M. J. Davis } \\ 1832 & \text { W. B. Jones } \\ 1832 & \text { J. W. Munford } \\ 1832 & \text { J. A. Van Den Avyle } \\ 1833 & \text { G. A. Knorovky } \\ 1840 & \text { R. J. Eagan } \\ 1841 & \text { R. B. Diegle } \\ 1841 & \text { N. R. Sorensen } \\ 3310 & \text { W. D. Burnett } \\ 6000 & \text { E. H. Beckner } \\ 6253 & \text { D. A. Northrop } \\ 6253 & \text { A. R. Sattler } \\ 6257 & \text { R. R. Beasley } \\ 6257 & \text { J. K. Linn } \\ 6258 & \text { B. J. Thorne } \\ 6300 & \text { R. W. Lynch } \\ 6310 & \text { T. O. Hunter } \\ 6311 & \text { L. W. Scully } \\ 6312 & \text { F. W. Bingham } \\ 6314 & \text { J. R. Tillerson } \\ 6330 & \text { W. D. Weart } \\ 6331 & \text { A. R. Lappin } \\ 6331 & \text { G. E. Barr } \\ 6331 & \text { S. J. Lambert } \\ 6331 & \text { W. B. Miller } \\ 6331 & \text { K. L. Robinson } \\ 6331 & \text { S. E. Shaffer } \\ 6331 & \text { C. L. Stein (11) } \\ & \end{array}$

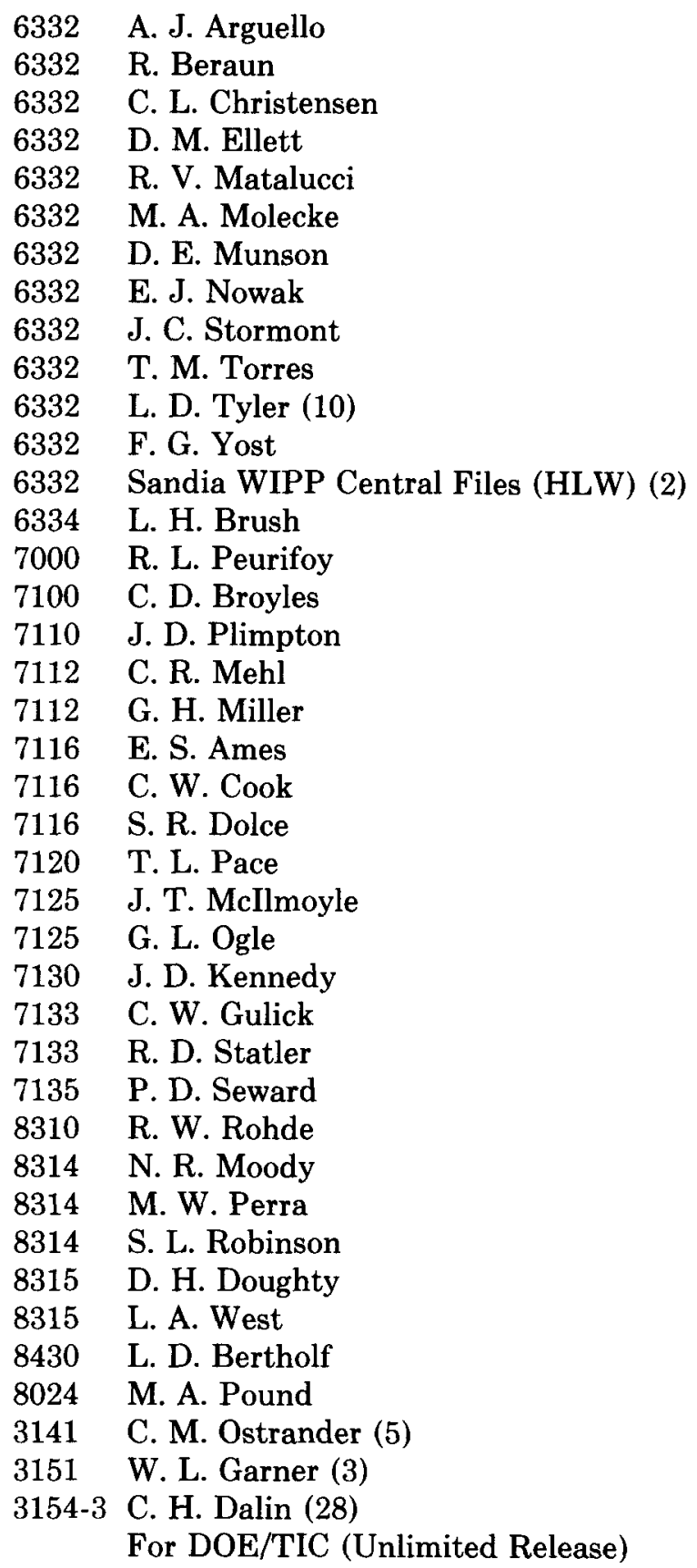

